\title{
The hippocampus of the eastern rock sengi: cytoarchitecture, markers of neuronal function, principal cell numbers, and adult neurogenesis
}

\author{
Lutz Slomianka ${ }^{1}$, Tanja Drenth ${ }^{1}$, Nicole Cavegn ${ }^{1}$, Dominik Menges ${ }^{1}$, Stanley E. Lazic ${ }^{2}$, \\ Mashudu Phalanndwa ${ }^{3,4}$, Christian T. Chimimba ${ }^{3,5}$ and Irmgard Amrein ${ }^{1}$ \\ 1 Institute of Anatomy, University of Zürich, Zürich, Switzerland \\ 2 In Silico Lead Discovery, Novartis Institutes for Biomedical Research, Basel, Switzerland \\ ${ }^{3}$ Mammal Research Institute, Department of Zoology and Entomology, University of Pretoria, Hatfield, South Africa \\ ${ }^{4}$ Western Cape Nature Conservation Board (CapeNature), Cape Town, South Africa \\ ${ }^{5}$ Department of Science and Technology-National Research Foundation Centre of Excellence for Invasion Biology, Department of Zoology and Entomology, \\ University of Pretoria, Hatfield, South Africa
}

\section{Edited by:}

Kathleen S. Rockland, Boston

University School Medicine, USA

\section{Reviewed by:}

Alino Martinez-Marcos, Universidad de Castilla, Spain

Fiorenzo Conti, Universita Politecnica delle Marche, Italy

\section{*Correspondence:}

Lutz Slomianka, Institute of Anatomy, University of Zürich, Winterthurerstr 190, 8057 Zürich, Switzerland e-mail:slomianka@anatom.uzh.ch
The brains of sengis (elephant shrews, order Macroscelidae) have long been known to contain a hippocampus that in terms of allometric progression indices is larger than that of most primates and equal in size to that of humans. In this report, we provide descriptions of hippocampal cytoarchitecture in the eastern rock sengi (Elephantulus myurus), of the distributions of hippocampal calretinin, calbindin, parvalbumin, and somatostatin, of principal neuron numbers, and of cell numbers related to proliferation and neuronal differentiation in adult hippocampal neurogenesis. Sengi hippocampal cytoarchitecture is an amalgamation of characters that are found in CA1 of, e.g., guinea pig and rabbits and in CA3 and dentate gyrus of primates. Correspondence analysis of total cell numbers and quantitative relations between principal cell populations relate this sengi to macaque monkeys and domestic pigs, and distinguish the sengi from distinct patterns of relations found in humans, dogs, and murine rodents. Calretinin and calbindin are present in some cell populations that also express these proteins in other species, e.g., interneurons at the stratum oriens/alveus border or temporal hilar mossy cells, but neurons expressing these markers are often scarce or absent in other layers. The distributions of parvalbumin and somatostatin resemble those in other species. Normalized numbers of PCNA+ proliferating cells and doublecortin-positive ( $\mathrm{DCX}+$ ) differentiating cells of neuronal lineage fall within the overall ranges of murid rodents, but differed from three murid species captured in the same habitat in that fewer DCX+ cells relative to PCNA+ were observed. The large and well-differentiated sengi hippocampus is not accompanied by correspondingly sized cortical and subcortical limbic areas that are the main hippocampal sources of afferents and targets of efferents. This points to intrinsic hippocampal information processing as the selective advantage of the large sengi hippocampus.

Keywords: Macroscelididae, comparative neuroanatomy, calcium-binding proteins, somatostatin, correspondence analysis, dentate gyrus, proliferation, neuronal differentiation

\section{INTRODUCTION}

The small family of sengis or elephant shrews (Macroscelididae) was long placed within the order Insectivora, but is now considered to form an order by itself, the Macroscelidea (Rathbun, 2009). They have been positioned with the Anagalida (rodents and lagomorphs) or even been taken as living representatives of Condylarths, the predecessors of hoofed mammals (Holroyd and Mussell, 2005). Molecular studies point to other mammals now endemic to Africa (Afrotheria/Tethytheria, e.g., elephants, sirenians, aardvarks, and hyraxes) as their closest relatives (Smit et al., 2011). Sengis are generally small sized mammals and, with the exception of one species, they inhabit woods, bushland and dry boulder or gravel plains of the southern part of the continent (Rathbun,
2005, 2009). The radiation that gave rise to extant species dates to only $\sim 11$ million years ago (Smit et al., 2011), i.e., at about the time when also the house mouse and rat may have diverged (Michaux etal., 2002). Sengis live in facultative monogamy, a rare trait in mammals, and give birth to highly precocial young.

Based on a phylogenetic analysis of gross characters of the brain, the rufous sengi (Elephantulus rufescens) associated with insectivores (Johnson et al., 1982; Kirsch and Johnson, 1983). However, Stephan and colleagues (Stephan and Spatz, 1962; Stephan and Andy, 1964) noted the prominent development of olfactory and subcortical visual centers. Based on these and other morphological observations and reflecting the later taxonomic changes, 
Stephan grouped the dusky footed sengi (Elephantulus fuscipes) and checkered sengi (Rhynchocyon cirnei) as macrooptic insectivores, which clearly deviated from his basal and higher insectivores in the relative size of the entire brain as well as that of major brain divisions. The most notable deviation was found for the hippocampus, which is 3.5 times larger than that of basal insectivores (Stephan, 1961; Stephan and Andy, 1964), larger than that of most primates, and equal in relative size to that of humans (Stephan, 1983). This observation confirmed the rather graphic early description of the appearance of sengi brains, including the eastern rock sengi (Elephantulus myurus) that we investigated, by Le Gros Clark (1928), who found the hippocampus to be an "enormous mass," "hypertrophied," and "immense and seemingly bizarre" developed. The few later studies of sengi neuroanatomy can still be comprehensively reviewed. Sanides and Sanides (1974) grouped Elephantulus with insectivores based on the large size of neocortical stellate cells and their extensive dendritic arbors when compared to rodents and primates. Sensory cortices of the cape sengi (Elephantulus edwardii), with emphasis on the somatosensory cortex, were mapped, found to be well-developed, yet without the cytochrome oxidase signature that allows the anatomical identification of these areas in other mammals (Dengler-Crish et al., 2006). Based on the distributions of cortical interneuron types characterized by the presence of calcium-binding proteins, of non-phosphorylated neurofilament containing neurons and glial fibrillary acidic protein (GFAP) expression, sengis, represented by a single specimen of the black and rufous sengi (Rhynchocyon petersi), were grouped with other afrotherian and xenarthran species and suggested to express distributions observed early in mammalian cortical evolution (Sherwood et al., 2009). A survey of the eastern rock sengi serotonergic, catecholaminergic, and cholinergic systems revealed an unusual presence of presumptive cholinergic neurons in the superior and inferior colliculi and cochlear nucleus, while other aspects of the distribution of markers for these systems did not deviate grossly from patterns observed in other eutherian mammals (Pieters et al., 2010). Notably, there have been no studies that followed up on what makes the sengi forebrain stand out among other mammals - their very large hippocampus.

In this study, we provide a general description and discussion of the cytoarchitecture of the hippocampus of the eastern rock sengi, the numbers of its principal neurons and the distribution of interneuron populations characterized by the expression of calcium-binding proteins and somatostatin. Of particular interest to us is how a very large hippocampus impacts on adult hippocampal neurogenesis (AHN). The observations that, in Murinae, a large habitat can be associated with either a large dentate gyrus and a low level of AHN or with a smaller dentate gyrus and a high level of AHN (Amrein et al., 2004a,b) suggest that species of this group may pursue different strategies to satisfy dentate information processing needs. Low levels of AHN in primates (Eriksson et al., 1998; Kornack and Rakic, 1999; Jabès et al., 2010; Amrein etal., 2011; Marlatt et al., 2011) may find their explanation in their large hippocampus (Stephan, 1975, 1983). This idea was put to the test in the sengi dentate gyrus by assessing cell proliferation, neuronal differentiation, and cell death.

\section{MATERIALS AND METHODS ANIMALS}

Seven female (body weight: 44-62 g) and seven male (body weight: 40-56 g) eastern rock sengis (Elephantulus myurus, Figure 1) were caught in Sherman life traps at the Goro Game Reserve, Limpopo Province, South Africa (Permit 0089-CPM-401-00004, CITES and Permit Management Office, Department of Environmental Affairs, Limpopo Province). Tissues were harvested from animals euthanized under projects in accord with the ethics guidelines of South Africa (University of Pretoria Clearance EC028-07) and the guidelines of the American Society of Mammalogists (Gannon et al., 2007). After trapping, animals were deeply anesthetized with pentobarbital $(50 \mathrm{mg} / \mathrm{kg}$ ), weighed and perfused transcardially using heparinized, cold phosphate buffer saline (PBS, pH 7.4) followed by $0.6 \%$ sodium sulfide in phosphate buffer and, finally, cold 4\% paraformaldehyde solution in PBS with $15 \%$ picric acid (PFA-PA). The brains were removed, weighed, separated into hemispheres and post-fixed overnight. Thereafter all right hemispheres and two left hemispheres were transferred to $30 \%$ sucrose solution for cryoprotection. The remaining left hemispheres were conserved in fresh PFA-PA for plastic embedding.

\section{HISTOLOGY AND IMMUNOHISTOCHEMISTRY}

The left hemispheres of 12 animals were dehydrated and embedded in glycol methacrylate (Technovit 7100, Heraeus Kulzer GmbH, Wehrheim/Ts, Germany) according to the manufacturer's instructions but with extended infiltration times (Amrein and Slomianka, 2010). Series of every sixth $20 \mu \mathrm{m}$ thick horizontal section were mounted, one series was Giemsa-stained (Giemsa stock solution 1.09204.0500, Merck, Darmstadt, Germany) following the protocol of Iñiguez et al. (1985) and one series of two animals was Timm-stained (Danscher and Zimmer, 1978).

Twelve series of $40 \mu \mathrm{m}$ thick frozen sections were cut from the right hemispheres (12 sagittal, one coronal and one horizontal) and two left hemispheres (one coronal and one horizontal). Sections were collected in cryoprotectant and stored at $-20^{\circ} \mathrm{C}$ until further processing. Details of the immunohistochemical

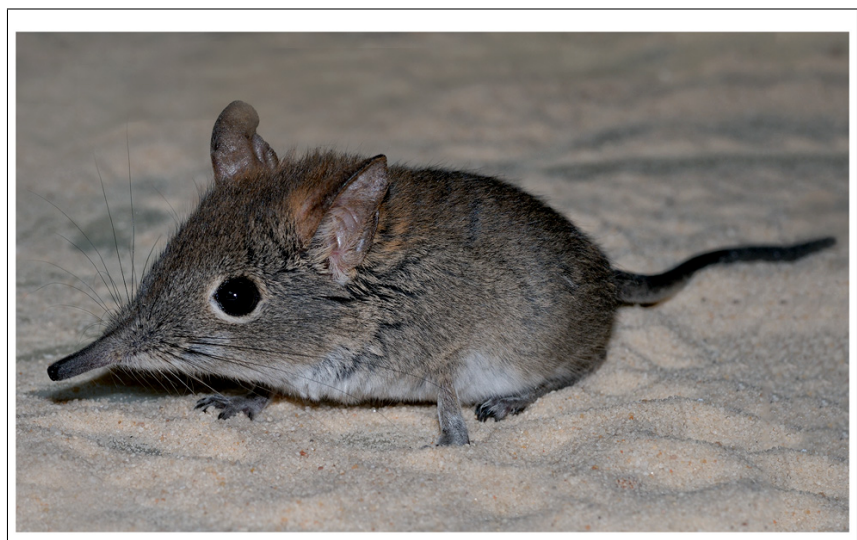

FIGURE 1 | The eastern rock sengi, Elephantulus myurus (courtesy of Heike Lautermann, Department of Zoology, University of Pretoria, South Africa). 
Table 1 | Antigen specific details of the immunohistochemical procedures.

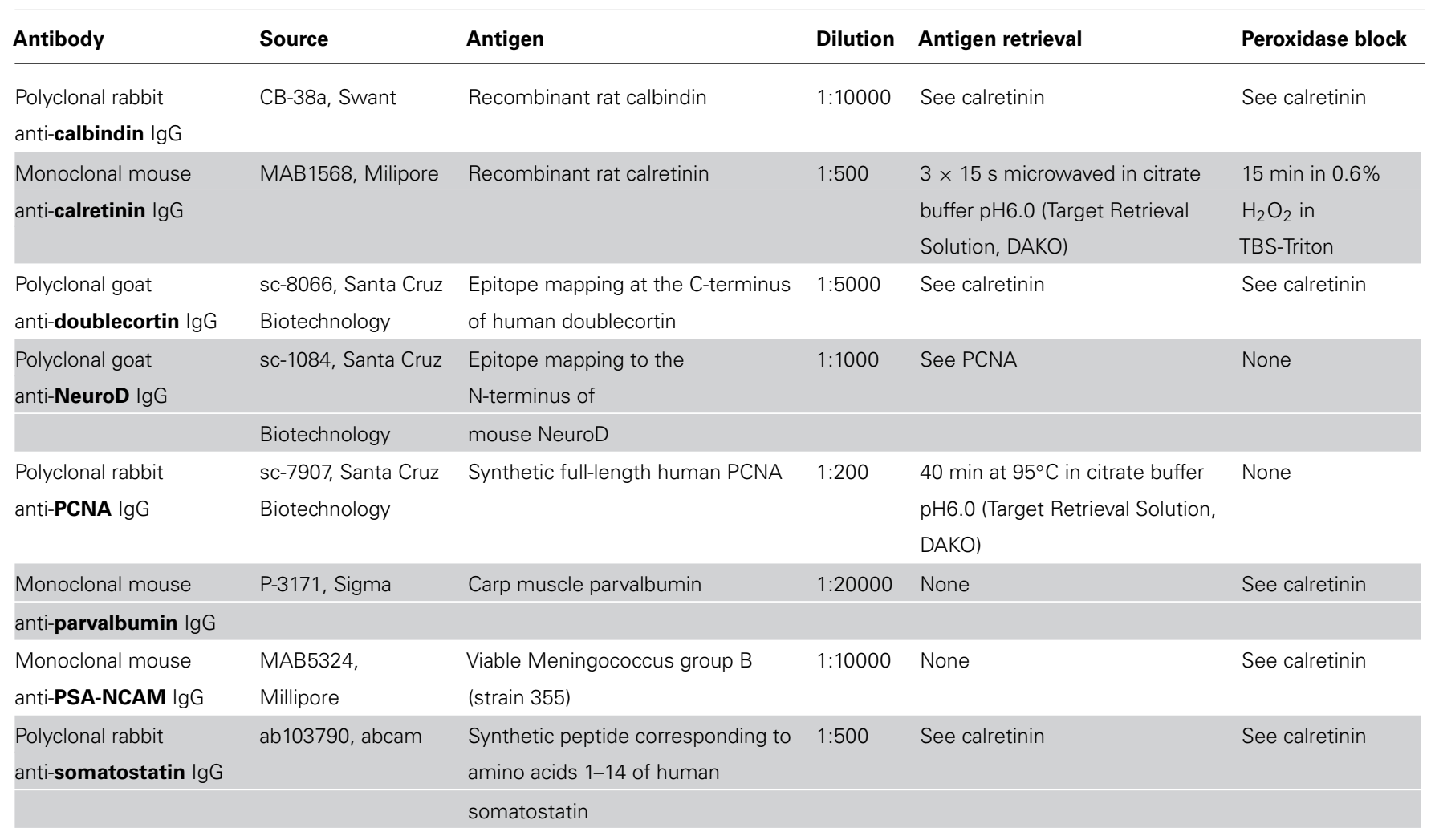

procedures (antibody, source, dilution, antigen, antigen retrieval) are listed in Table 1. Between all steps, sections were washed with Tris-Triton (TBS pH 7.4 with $0.05 \%$ Triton) and, after incubation with primary antibody, with TBS only. After preincubation with $2 \%$ normal serum, $0.2 \%$ Triton, and $0.1 \%$ bovine serum albumin in TBS, sections were incubated with the primary antibody overnight at $4^{\circ} \mathrm{C}$. Incubation in secondary antibody (1:300) and $\mathrm{ABC}$ solution (Vectastain Elite Kits, Vector Laboratories, Burlingame, CA, USA) followed the manufacturer's instructions. Finally, sections were diaminobenzidine-stained, dehydrated and mounted.

For all antigens, mouse forebrain sections were processed in the same batch. None of the antibodies stained structures that, based on concurrently processed mouse sections and published data on the distributions of the antigens, were regarded unspecific. Several attempts to stain proliferating cells using the marker Ki67 failed. A similar failure was noted for another Afrotherian species (Patzke et al., 2013).

\section{QUANTITATIVE PROCEDURES}

Cell numbers of the principal cell populations of the dentate gyrus, hippocampus, and subiculum were estimated in Giemsastained sections of methacrylate embedded left hemispheres of four females and four males. Borders between cell populations (illustrated in Figure 2) are described in the results section on cytoarchitecture.

To obtain the estimates, we used the optical fractionator method (West et al., 1991) with StereoInvestigator 10 software
(MBF Bioscience, Williston, VT, USA). Every second section of the mounted series, i.e., every 12 th section, was sampled with $10 \mu \mathrm{m}$ high disectors and $2 \mu \mathrm{m}$ top guard zones at $210 \mu \mathrm{m}$ intervals along the $x$ - and $y$-axis. Section thickness was estimated at every 10th sampling site. Sampling parameters that differed between cell populations, the mean numbers of sampling sites, cells counted, total number estimates (based on numberweighted section thickness; Dorph-Petersen et al., 2001), and coefficients of error (CE) of the individual estimates for $m=0$ (Gundersen et al., 1999; Slomianka and West, 2005) are listed in Table 2.

Cell numbers of PCNA-positive (PCNA+) proliferating cells and doublecortin-positive (DCX + ) type $2 \mathrm{~b}$-progenitors and young neurons were estimated in the immunohistochemically stained sagittal series of the right hemispheres. PCNA+ cells were counted exhaustively using area and thickness sampling fractions of 1 , but omitting cells in the top focal plane of the sections from the counts. DCX + cells were counted using a $30 \mu \mathrm{m} \times 30 \mu \mathrm{m}$ unbiased counting frame applied at steps of $150 \mu \mathrm{m}$ along both the $x$ - and $y$-axis. The thickness sampling fraction was again 1, omitting cells in the top focal plane from the counts.

The ratio $\mathrm{CE}^{2} / \mathrm{CV}^{2}$ (CV: group standard deviation/group mean) was calculated to ascertain the contribution of the estimation procedure to group variances (Tables 2 and 4). To compare AHN of the sengi with other species, we normalized cell counts by dividing them by the number of resident granule cells (Amrein et al., 2011). 

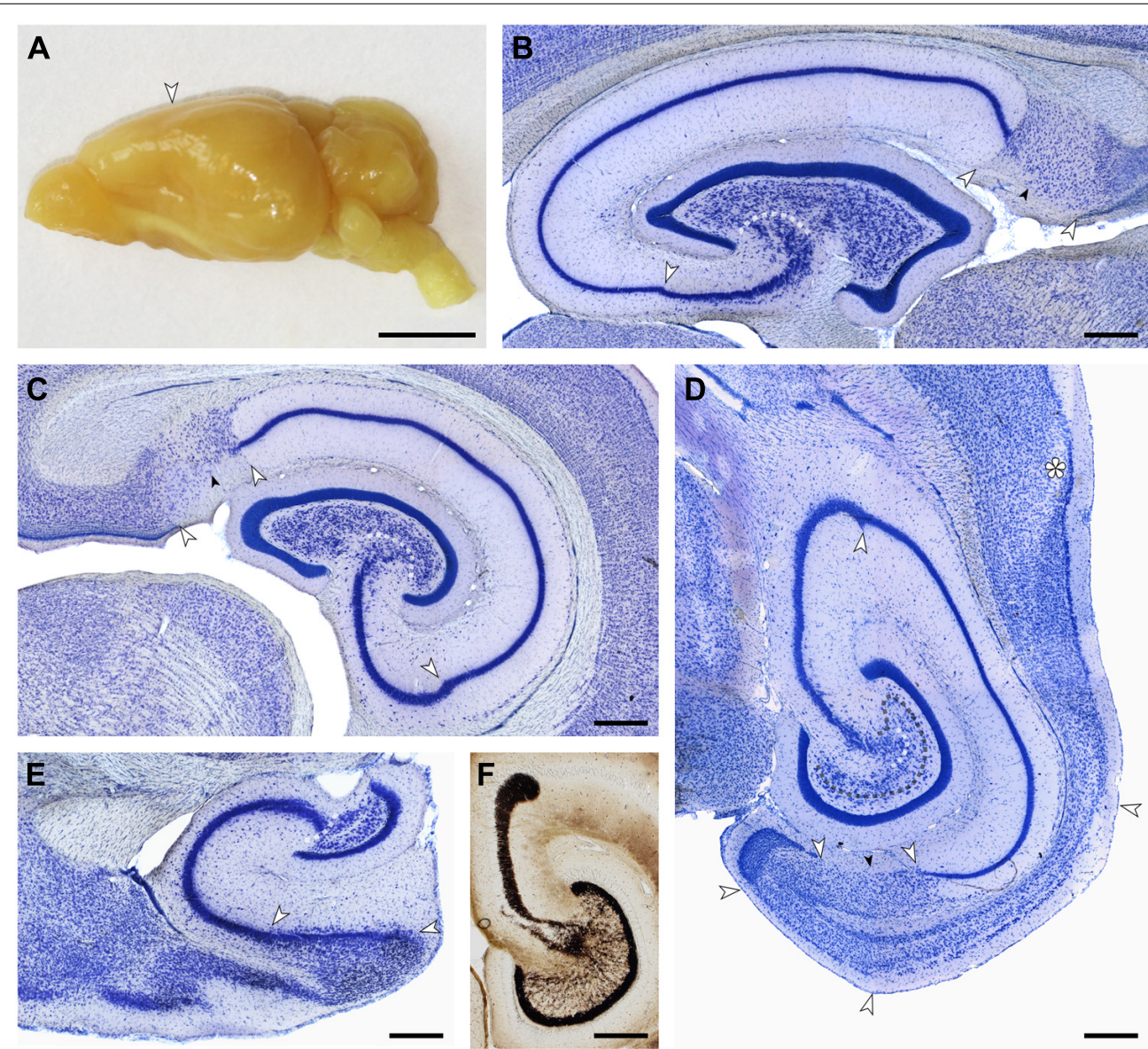

FIGURE 2 | (A) Macroscopic lateral view of the eastern rock sengi brain. The posterior expansion of the hemisphere largely reflects the shape of the underlying hippocampus. Scale bar: $5 \mathrm{~mm}$. (B-E) Light arrows and light dotted line mark the borders between hippocampal fields. Small dark arrows mark the border between the proximal and distal parts of the subiculum. (B,C,E) $40 \mu \mathrm{m}$-thick frozen sections; (D,F) $20 \mu \mathrm{m}$-thick plastic embedded section. Scale bars in (B-F) $0.5 \mathrm{~mm}$. (B) Sagittal section of the septal hippocampus located at the transition from the first to the second hippocampal quarter. (C) Frontal section of the hippocampus located midway along the septotemporal hippocampal axis. (D) Horizontal section of the temporal hippocampus located at the transition from the third to the fourth hippocampal quarter. The dark dotted line marks the tentative border between the reflected blade of CA3 and the mossy cell layer. Asterisk: sectioning artifact. (E) Sagittal section of the temporal pole of the hippocampus. The plane of section corresponds to (B). (F) Timm-stained section corresponding to (D) showing a dense, narrow band of staining below the granule cell layer from which individual strands extend to coalesce into the CA3 mossy fiber zone. At the distal end of CA3, mossy fibers form a distinct end-bulb.

\section{AGE ESTIMATION}

Eastern rock sengis are seasonal breeders and pups are born between September and March (Rathbun, 2005). Based on the time of capture (September), we expect that none of the animals in this sample is younger than 6 months or older than 12 months. We measured lens weight and bone lines (Cavegn et al., 2013), calculated the means for each measurements and assigned a rank as a percentage of the means. Ranks were linearly transformed into tentative ages in months.

\section{STATISTICS}

The degrees of divergence/convergence of connections within the hippocampal region were calculated by dividing the number of cells in the projecting populations by the number of cells in the target populations for the eastern rock sengi and seven other species for which data sets obtained by design-based stereological techniques were available (see Table 3). The definitions of hippocampal fields in these studies were compatible with those used here. In particular, if a CA4 (a reflected blade of the CA3 pyramidal cell layer, Rosene and van Hoesen, 1987) was present, it was included in the cell counts of the hilus. A one-way ANOVA (SPSS 19, IBM SPSS Statistics) was used to test degrees of divergence/convergence for main species effects, with Bonferronicorrected post hoc testing for differences between species pairs. $P$-values less than 0.05 (two-tailed) were considered significant.

$\mathrm{R}$ (version 2.15.3) was used for the following analysis. The relationship between species and hippocampal cell population sizes was visualized with correspondence analysis (MADE4 R package, Culhane et al., 2005), which is similar to principal components analysis, but uses a weighted Euclidean distance to account for large differences in the absolute size of the neuron populations. Values for each animal were scaled by subtracting the mean of all principal neuron populations of that animal and dividing by their standard deviation. All animals therefore have cell counts with 
Table 2 | Unilateral hippocampal principal cell numbers (rounded to the next 1000) in the eastern rock sengi hippocampus and sampling parameters (males, $n=4$; females $n=4$ ).

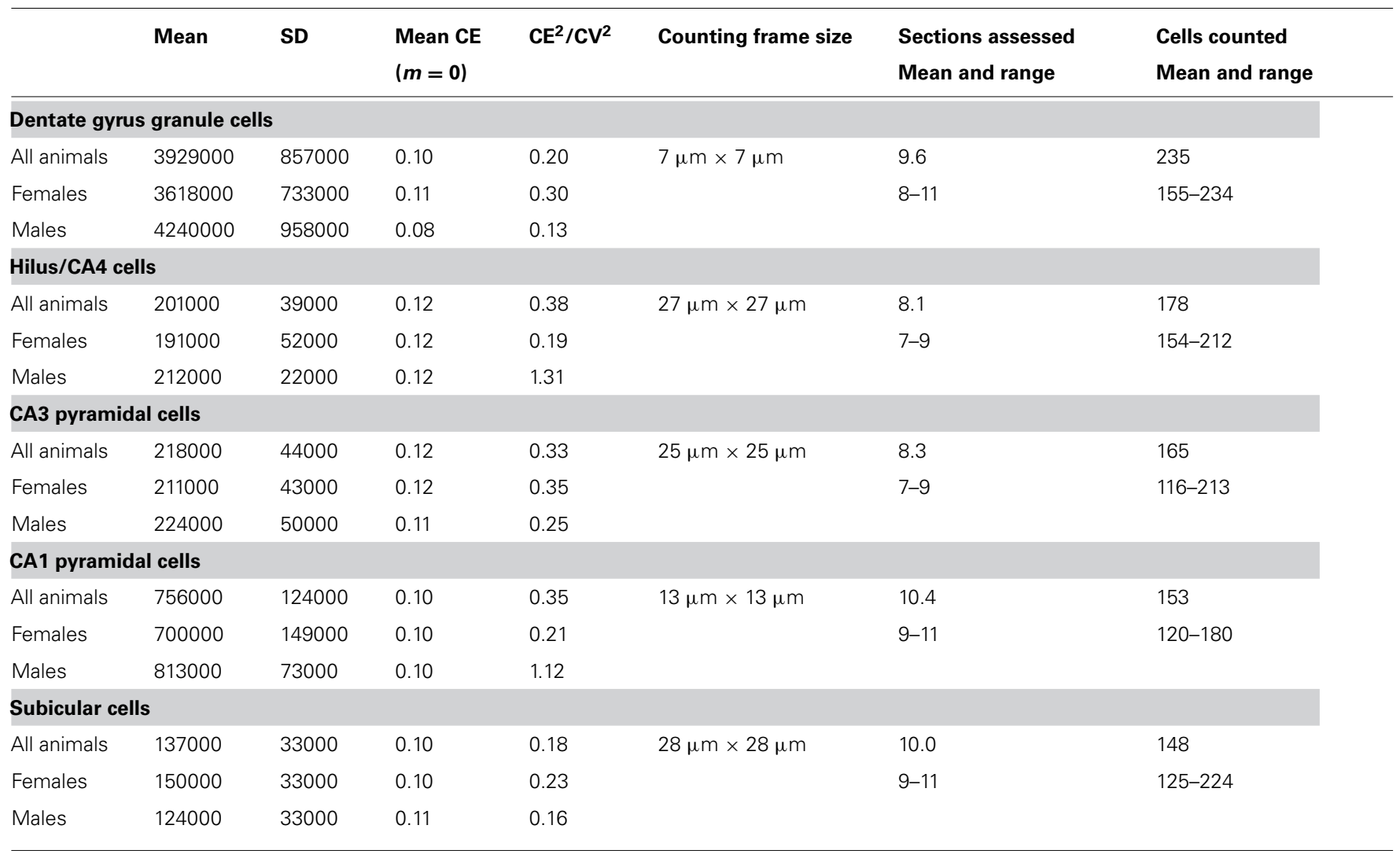

Table 3 | The degree of convergence or divergence (source cell number/target cell number) along the chain of hippocampal projections from the dentate granule cells to the subiculum. Bold numbers are statistically different from the value observed in the eastern rock sengi $(P$-values in parenthesis).

\begin{tabular}{|c|c|c|c|c|}
\hline & DG $\rightarrow$ hilus/CA4 & $\mathrm{DG} \rightarrow \mathrm{CA3}$ & $\mathrm{CA} 3 \rightarrow \mathrm{CA} 1$ & CA1 $\rightarrow$ subiculum \\
\hline Eastern rock sengi (Elephantulus myurus) & 19.6 & 18.4 & 0.29 & 5.8 \\
\hline House mouse (Mus musculus) $^{1}$ & $24.6(0.985)$ & $3.84(<0.001)$ & $0.73(<0.001)$ & $1.4(<0.001)$ \\
\hline Brown rat (Rattus norvegicus) $)^{2}$ & $20.9(1.000)$ & $4.8(<0.001)$ & $0.78(<0.001)$ & $1.1(<0.001)$ \\
\hline Harvest mouse (Micromys minutus) ${ }^{3}$ & $45.5(<0.001)$ & $4.4(<0.001)$ & $1.1(<0.001)$ & $1.4(<0.001)$ \\
\hline Dog (Canis lupus familiaris $)^{4}$ & $24.4(0.788)$ & $6.1(<0.001)$ & $0.33(1.000)$ & $1.4(<0.001)$ \\
\hline Tree shrew (Tupaia glis) ${ }^{6}$ & & & $0.73(<0.001)$ & $2.1(<0.001)$ \\
\hline Rhesus monkey (Macaca mulatta) ${ }^{7}$ & $20.7(1.000)$ & $16.4(1.000)$ & $0.38(1.000)$ & $2.4(<0.001)$ \\
\hline Human $\left(\right.$ Homo sapiens) ${ }^{8}$ & $11.4(<0.001)$ & $6.56(<0.001)$ & $0.24(1.000)$ & $2.6(<0.001)$ \\
\hline
\end{tabular}

${ }^{1} n=7$, Sources: Fabricius etal., 2008

$2 n=15$, Sources: West etal., 1991; Hosseini-Sharifabad and Nyengaard, 2007; Fitting et al., 2010

${ }^{3} n=5$, M.J. West and L. Slomianka, unpublished data

${ }^{4} n=10$, Sources: Siwak-Tapp etal., 2008

${ }^{5} n=5$, Sources: original data kindly provided by the authors, Holm and West, 1994

$6_{n}=11$, Sources: Keuker etal., 2004

${ }^{7} n=8$, Sources: Keuker etal., 2003a

$8 n=73$, Sources: West and Gundersen, 1990; West, 1993; Simic etal., 1997; Harding et al., 1998; Korbo etal., 2003 
Table 4 | Unilateral dentate gyrus neurogenesis related cell numbers in the eastern rock sengi (rounded to the next 100 for PCNA and doublecortin and the next 10 for apoptotic cells) and sampling parameters (CEs and $\mathrm{CE}^{2} / \mathrm{CV}^{2}$ rounded to two decimals).

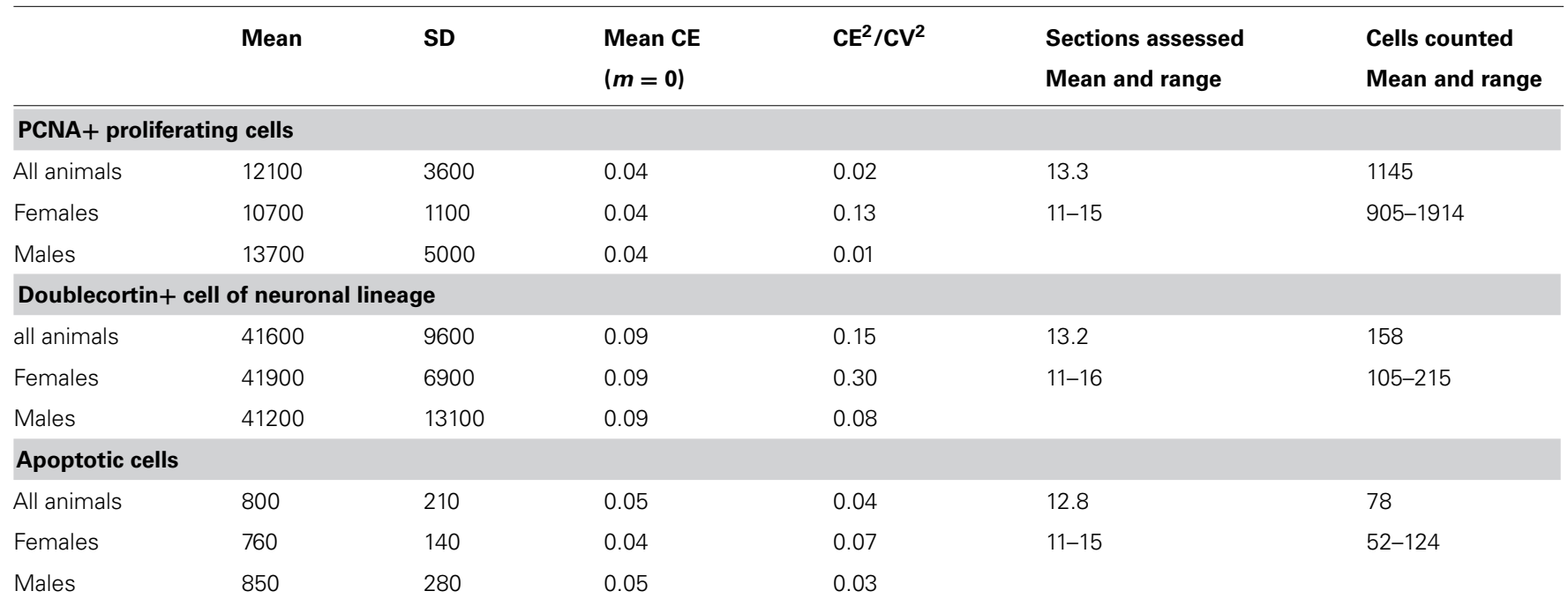

All animals: $n=12$, females: $n=6$, males: $n=6$.

a mean of zero and a standard deviation of one across regions, but the relative differences between regions for each animal are retained. Only animals that had values for all cell populations that were estimated in the sengi were included.

Correlations between tentative age, and the numbers of PCNA+ proliferating cell, DCX + young neurons and apoptotic cells were tested using Pearson's $r$ (SPSS 19, IBM SPSS Statistics). In that a negative correlation with age and positive correlations between the three cell populations were expected, one-tailed tests were performed and $p$-values less than 0.05 were considered significant.

Gender differences were tested using a one-way ANOVA (SPSS 19, IBM SPSS Statistics) with or without tentative age as a covariate. $P$-values less than 0.05 (two-tailed) were considered significant.

\section{RESULTS}

All descriptions refer to the typical pattern observed at midseptotemporal levels of the dentate gyrus, hippocampus, and subiculum. Septotemporal changes or gradients are mentioned after the description of the typical pattern.

\section{HIPPOCAMPAL CYTOARCHITECTURE \\ Dentate gyrus}

Small, round cells with a preference to be located either superficially or at depth are the most common type of neuron in the cell-sparse dentate molecular layer $(\mathrm{ml})$. The granule cell layer $(\mathrm{gcl})$ is $12-15$ cells wide and has sharp boundaries to both the molecular cell layer and, in particular, the hilus (Figure 3A). The layer only forms distinct crests at the septal pole of the dentate gyrus (Figure 2B). Granule cells are densely packed and tend to form columns that span the $g c l$. Their large nuclei with one distinct and large nucleolus - a characteristic of all neuronal cell populations in the sengi hippocampus - are surrounded by a very narrow rim of cytoplasm. Pyramidal-shaped cells are embedded in the lower margin of the $g c l$ (1, Figure 3A), while ovoid cells slightly larger than granule cells and with a larger cytoplasm are found at the upper $g c l$ border (2, Figure 3A). A narrow hilar plexiform layer $(h p l)$, which contains rare spindle-shaped cells that are oriented parallel to the $g c l$ (3, Figure $3 \mathbf{A}$ ) and rare ectopic granule cells, delimits the $g c l$ from the hilar polymorphic cell layer $(h p c l)$. Immediately below the $h p l$, a sparse population of large polygonal cells (4, Figure 3A), with 2 or 3 large primary dendrites in the plane of the section, gradually merges with the dominant cell population of the loosely packed $h p c l-$ slightly smaller ovoid to polygonal cells with 3 or more primary dendrites extending from their soma (5, Figure 3A). A third population is formed by distinctly smaller and darker staining cells of typically triangular appearance (6, Figure 3A) that are scattered throughout the hpcl.

The CA3 pyramidal cell layer ( $C A 3 p c l)$ inserts into the $h p c l$ close to the suprapyramidal limit of the $h p c l$ (Figures 2B-E). While the $h p c l$ forms a continuous wide band septally (Figures 2B,C), it is separated into two tiers temporally (Figures 2D,E), leading us to believe that the dominant cell population in the $h p c l$ represents modified pyramids of a reflected blade of the CA3pcl. This interpretation is supported by the distribution of mossy fiber terminals (Figure 2F) that form a dense narrow band below the $g c l$ thereby delimiting cells embedded in the band from the deeper part of the hpcl.

\section{Hippocampus, CA3}

The CA3 stratum lacunosum moleculare $(C A 3 s l m)$ is characterized by a distinctly higher density of glial cells than in the subjacent layers and frequent very small ovoid neurons. A few larger neurons align with the border between the CA3slm and CA3 stratum radiatum (CA3sr). The CA3pcl forms a typically four cells deep, dense band (Figure 3B) that widens considerably (Figures 2B-D) both at the transition to the $h p c l$, where the CA3pcl fans out into the $h p c l$, and to the CA1 pyramidal cell layer $(C A 1 p c l)$. Few dark 

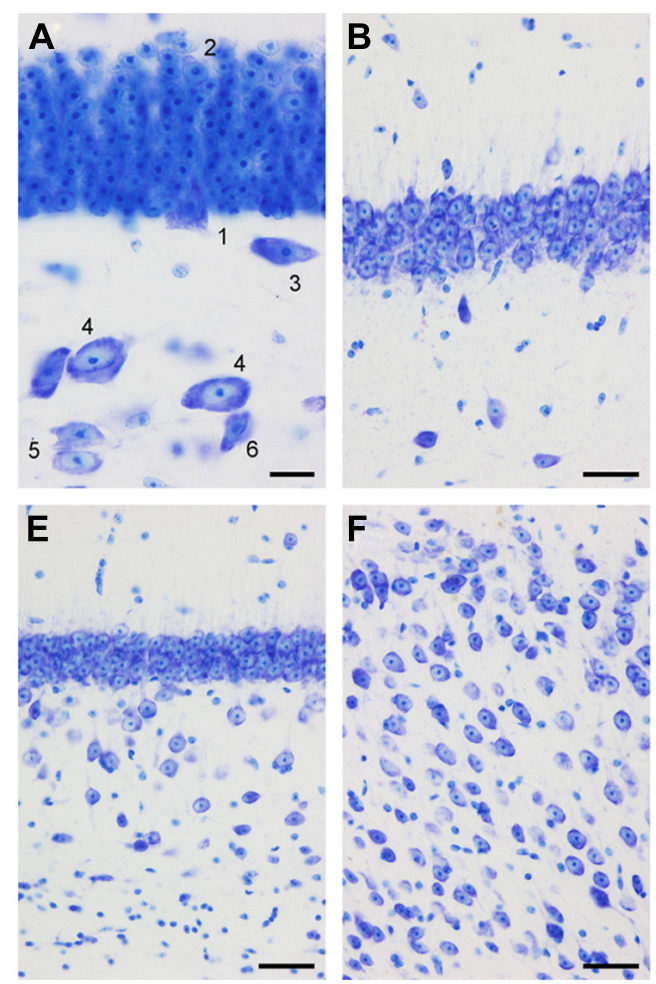

FIGURE 3 | Mid-septotemporal (unless noted otherwise) dentate gyrus and hippocampus in plastic embedded $20 \mu \mathrm{m}$-thick horizontal sections. (A) Composite of two focal planes of the dentate gyrus granule cell layer, hilar plexiform layer $(h p /)$, and hilar polymorphic cell layer $(h p c l)$. Cell 3 was cloned into this image from an adjacent field of view. 1, pyramidal (basket) cell; 2 . large granule cell; 3, spindle-shaped cell of the hpl; 4; large polygonal
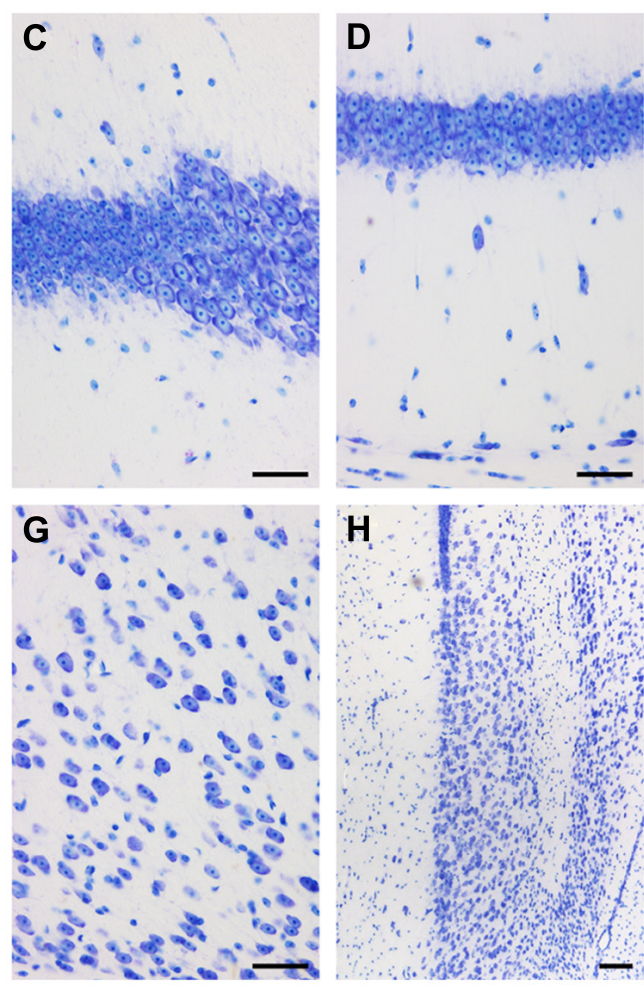

neurons; 5, ovoid neurons, the dominant population of the hpcl; 6, small dark triangular cell. (B) CA3. (C) Transition from CA3 to CA1. (D) Composite of two focal planes of the CA1 pyramidal cell layer (CA1pcl), stratum oriens (CA1so), and stratum oriens/alveus border (so/a). (E) Temporal CA1pcl. (F) Proximal subicular cell layer (Scl). (G) Distal Scl. (H) Temporal subiculum. Scale bars: (A) $20 \mu \mathrm{m}$; (B-G) $50 \mu \mathrm{m}$; (H), $100 \mu \mathrm{m}$. polymorphic cells are embedded in the deep part of the CA3pcl. Proximally, i.e., close to the dentate gyrus, ovoid, spindle-shaped, and small, dark pyramidal neurons are common (Figure 3B) in the adjacent CA3 stratum oriens (CA3so) and CA3sr. Their density decreases distally toward the transition to CA1. Distally, large round cells are seen in the CA3so and a group of smaller cell bodies of often spindle-shaped but variable morphologies is scattered close to the border between CA3so and the alveus. Their density decreases toward proximal CA3. Gradients in the distribution of cells outside the CA3pcl largely reflect differences in the densities of cells that express markers of inhibitory neurons (see below).

Cytoarchitectural characteristics of CA3 are conserved along the septotemporal axis of CA3. However, in proportion to CA1, CA3 shortens septally along its proximo-distal axis while it elongates temporally (Figures 2B-E).

\section{Hippocampus, CA1}

Similar to the CA3slm, the CA1 stratum lacunosum moleculare $(C A 1 s l m)$ is glia-rich but small neurons are rare. Spindle-shaped cells are found at the border between the CA1slm and the CA1 stratum radiatum $(C A 1 s r)$ and align with it. The transition from the $C A 3 p c l$ to $C A 1 p c l$ is marked by a sudden decrease of the thickness of the $C A 1 p c l$ that also contains markedly smaller pyramidal cell bodies (Figure 3C). CA1 and CA3 pyramidal cells intermingle for a very short distance. The CA1pcl is densely packed and typically four cell bodies deep (Figure 3D) - temporally it tapers from the proximal to the distal end (Figure 2D). Very rare (one or two per section) darkly stained polymorph or pyramidal-shaped cells are embedded in the deep part of the CA1pcl. Neurons in the CA1sr and CA1 stratum oriens (CA1so) are rare, typically ovoid or spindle-shaped and oriented perpendicular to the $C A 1 p c l$ (Figure 3D). The distribution of neurons along the CA1so/alveus borders mirrors that of CA3 with cells being more frequent in proximal CA1 than in distal CA1. The CA1pcl ends abruptly at the subicular border (Figures 2B-D). Although the subicular cell layer $(S c l)$ undercuts CA1 slightly, it does so less than in laboratory mice or rats, and the border is typically very sharp throughout the radial extent of the deep hippocampal layers.

Cytoarchitectural characteristics of CA1 are conserved along most of the septotemporal axis (Figure 2). Only in the temporal one-quarter are scattered larger pyramidal cells located beneath the compact superficial layer (Figures $2 \mathrm{E}$ and $3 \mathrm{E}$ ) - first in the immediate vicinity of the subiculum and later beneath the distal one-third of the CA1pcl. CA1 and CA3 pyramidal cells do maintain their distinct difference in size along the entire septotemporal axis of the hippocampus. 


\section{Subiculum}

Due to oblique borders with CA1 and the presubiculum, the $\mathrm{Scl}$ forms a lozenge-shaped field (Figures 2B-D). It is divided into distal and proximal areas of roughly equal size. Proximally, a condensation of small neurons is seen at the border between the subicular plexiform layer $(S p l)$ and $S c l$ (Figure 3F). Beneath this condensed part of the proximal $S c l$, a visually homogenous population of neurons with large ovoid somata and one large apical dendritic trunk spans most of the $S c l$ (Figure 3F). Some smaller and darker cells are scattered within this population and become more frequent at the $S c l$ alveus border. In the deep part of the $S c l$ they are accompanied by a number of dark pyramidal-shaped somata. The superficial condensation of cells is absent in the distal part of the Scl. Cells are generally smaller and darker and morphologically more heterogeneous than in the proximal Scl (Figure 3G). Toward the alveus, the distal $S c l$ is delimited by a band of small elongated dark neurons that continues morphologically unchanged into the adjacent presubiculum.

Septally, the distal part of the $S c l$ expands to occupy most of the $S c l$ and the deep band of cells that delimits the $S c l$ from the alveus is absent. In the temporal one-quarter of the subiculum, the proximal part of the $S c l$ expands until it spans the entire proximodistal extent of the subiculum (Figure $3 \mathbf{H}$ ).

\section{HIPPOCAMPAL CELL NUMBERS}

The total number of neurons estimated to be present in the dentate $g c l$, hilus/CA4, CA3pcl, CA1pcl, and Scl of male and female animals are listed in Table $2 . \mathrm{CE}^{2} / \mathrm{CV}^{2}$ were typically below 0.5 , suggesting that only a minor part of the group variances originated from the estimation procedure.

Estimates tend to be slightly higher in males $(+6$ to $+17 \%)$ than in females (except for the subiculum: $-18 \%$ ). Significant sex differences could, however, not be observed for individual populations or total hippocampal cell number $(p=0.22-0.71)$ with the group sizes used.

Degrees of convergence and divergence are listed in Table 3 and compared to published data sets of other species that allowed calculating at least two values. The eastern rock sengi most closely resembles the macaque monkey until the subiculum is reached. The degree of convergence of CA1 pyramidal cells onto subicular neurons by far exceeds the values observed in all other species. Opposing but non-significant differences in CA1 and subicular cell numbers in male and female sengis did not result in a gender difference in convergence $[t(6)=-1.71 p=0.14]$.

Extending the analysis beyond the comparison of the sengi with other species, the results for the correspondence analysis are shown in Figure 4. Each point in Figure 4A is a single individual and the axes represent the reduction from five-dimensional space (where each hippocampal field is a separate axis) to two dimensions that capture most $(91 \%)$ of the variation in the original data. This allows multidimensional patterns to be visualized in two dimensions with only a small amount of information loss. Individuals close to each other in Figure 4A have similar cell count profiles across regions, and it can be seen that the three rodent species cluster together, as do sengis and rhesus monkeys. The three remaining species (human, dog, and pig) are fairly distinct. Figure 4B plots the brain region profiles (a reduction from 126-dimensional space with one axis for each individual) and can be used to determine which brain regions are responsible for species clusterings, along with the eight panels of species profiles (Figure 4C). Figures 4A,B are on the same scale and are often plotted on one graph, but were separated for clarity. The rodents are spatially close to CA3 (they are in the bottom left quadrant in both graphs), and the interpretation is that rodents have a relatively high number of cells in the CA3. This is clear from the species profile plots where the rodents have a "spike" in the CA3. Similarly, the rodents are far away from the CA4/hilus (bottom right) and CA1/2 (top right) regions, meaning that they have relatively few cells in these regions, which can also be seen in the species profile plots. The interpretation is the same for the other species and regions (e.g., humans have relatively high cell counts in the CA1/2 while the sengi has relatively few cells in the subiculum).

\section{MARKERS OF NEURONAL FUNCTION \\ Calretinin}

Dentate gyrus. The medial ( $m p p)$ and lateral ( $l p p)$ perforant pathways of the dentate $m l$ are virtually unstained (Figures 5A-C), which agrees with the absence of stained cell bodies in the layer II of the medial and lateral entorhinal cortices. The lpp and $m p p$ are sharply delimited from a well-stained commissural/associational zone $(c / a$, Figures 5B,C). Small strongly stained cell bodies are seen close to the hippocampal fissure (Figures $\mathbf{5 A}-\mathbf{C}$ ) and more frequently so over the suprapyramidal blade than the infrapyramidal blade of the $g c l$. One or two slender processes emanate from the cell bodies. When processes can be followed for some distance, they take on a weakly beaded appearance. Granule cells appear unstained. Rare (typically $<1$ per section) weakly stained pyramidal-shaped cell bodies are embedded in the lower aspect of the $g c l$. The $h p l$ is weakly stained and merges without clear border with the $h p c l$ that harbors few weakly stained, large, multipolar cell bodies (Figure 5B).

There are no staining gradients along the transverse axis of the dentate gyrus. Along the septotemporal axis, there are strong gradients in the appearance of the $c / a$ zone and the $h p c l$. The c/a zone is very weakly stained septally (Figure 5A). Staining increases toward temporal levels (Figures 5B,C) and becomes moderate before stained cell bodies become apparent in the $h p c l$ along the middle one-third of the dentate gyrus. Staining intensity of $h p c l$ cell bodies increases markedly toward the temporal pole (Figure 5C).

Hippocampus and subiculum. With few exceptions, the hippocampus appears unstained throughout its transverse and septotemporal extent. Small intensely stained cells similar to those in the dentate $\mathrm{ml}$ are present in CA3slm. Weakly stained pyramidal cell bodies form a deep band in the temporal CA3pcl (Figure 5D). Darkly stained polymorphic cell bodies located close to the CA1pcl and $C A 3 p c l$ are rare (typically $<1$ per section and $<10$ per series). A small field of fine terminal-like staining (Figure 5A) is seen at the transition from the CA1slm to the Spl. At the border between CA1 and the subiculum, a few small cells are embedded in this field (Figure 5A). The terminal-like staining expands temporally 

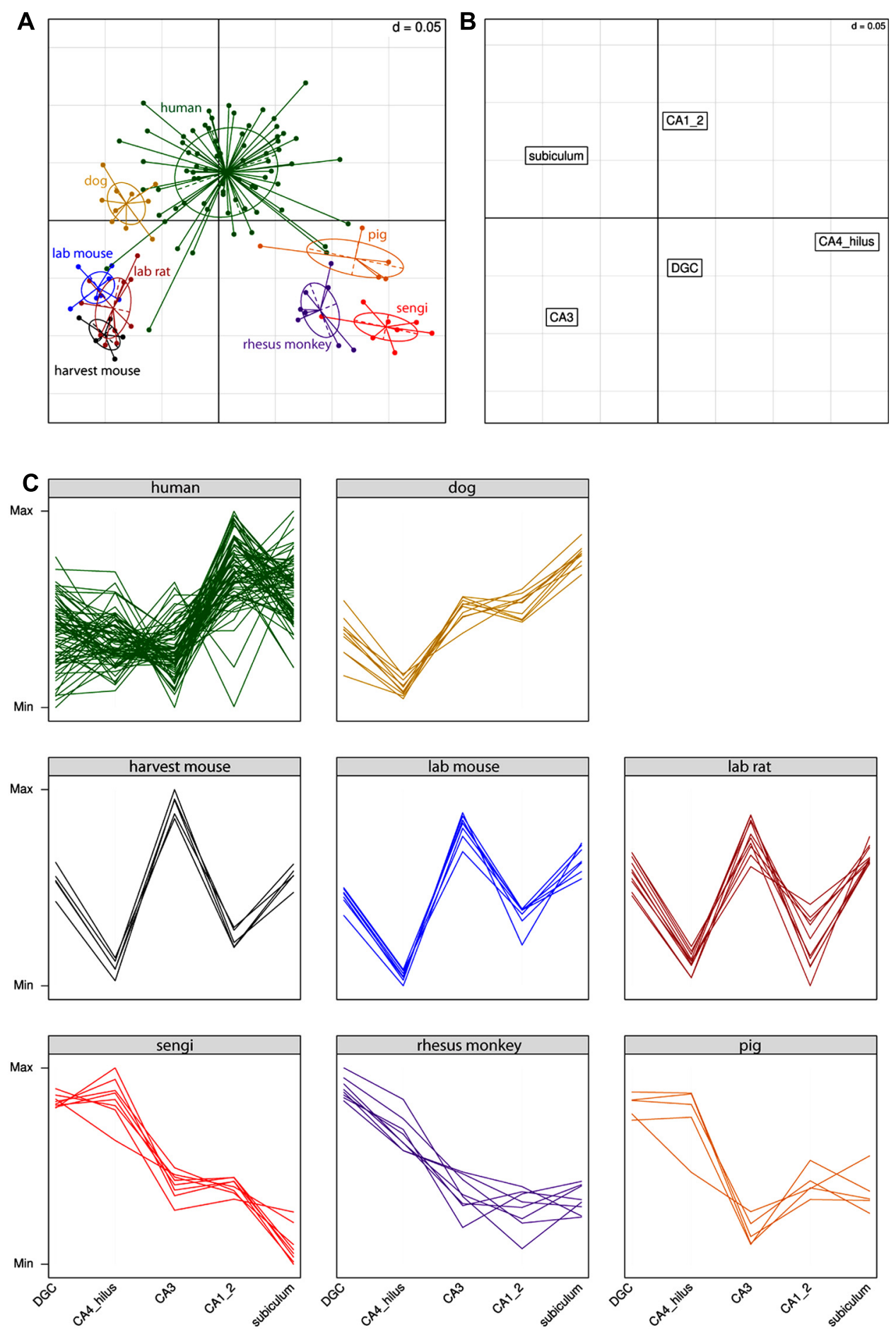

FIGURE 4 | Correspondence analysis (A,B) and species profile (C) plots show the relationships between cell counts and hippocampal fields. Species form distinct clusters (A) with phylogenetically similar species such as the rodents clustering close together. The spatial arrangement of hippocampal fields in (B) can be used to determine which fields are driving the species clusters. For example, the rodents are located in the bottom left quadrant in (A), as is the CA3 region in (B). This means that rodents have relatively high numbers of cells in the CA3 (and relatively few cells in the
CA4/hilus). These relationships can also be seen in the species profile plots (C), where each line represents an individual animal. The $y$-axes range from the minimum to the maximum value for each hippocampal field, and therefore the most relevant comparisons are across species for a given field (e.g., it can be determined that rodents have relatively more cells in the CA3 than humans). Note that it is not possible to determine from these graphs whether mice have a greater number of cells in the CA3 or dentate gyrus (DGC), as each field uses a different scale. 

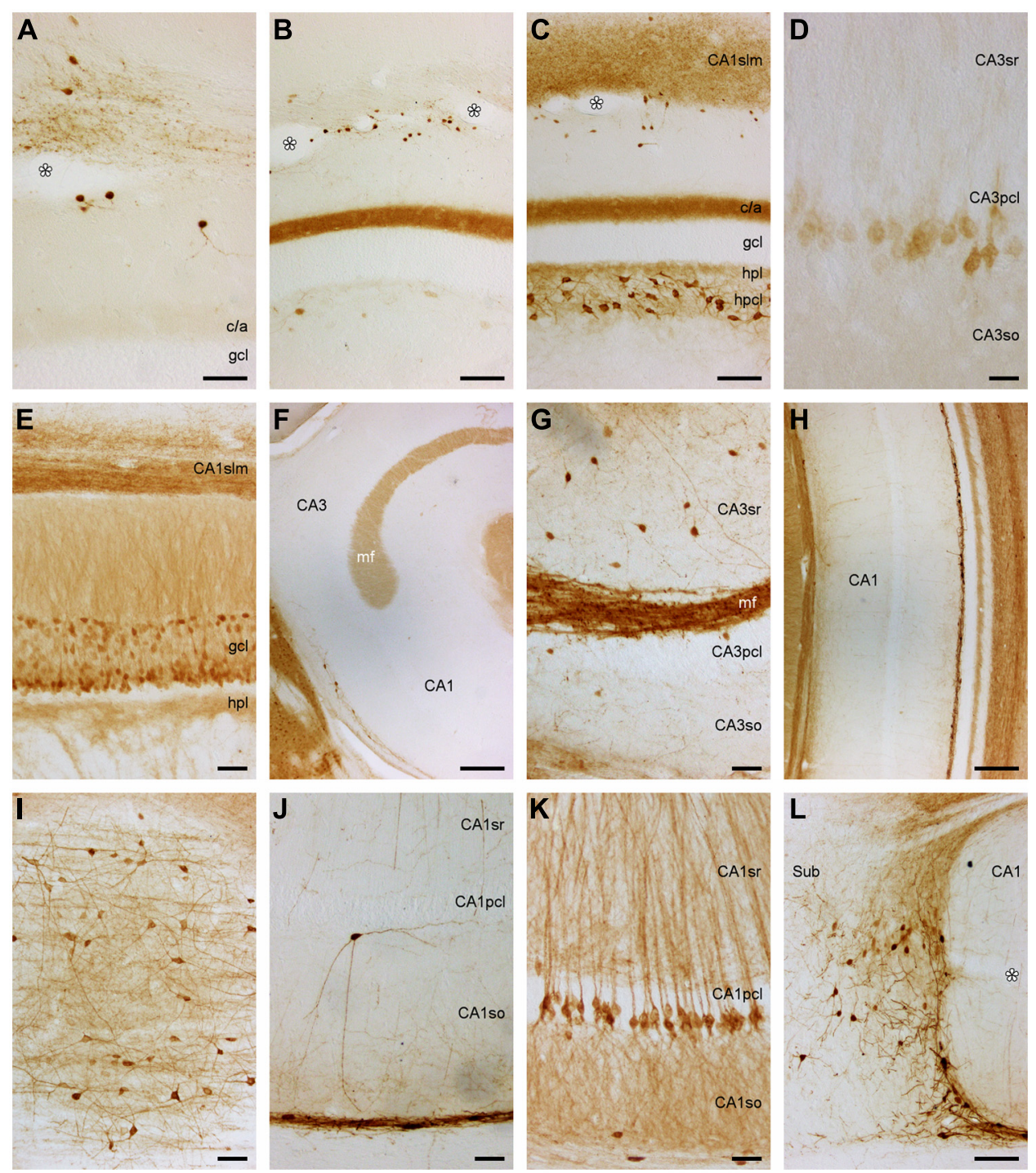

FIGURE 5 | Calretinin and Calbindin in the eastern rock sengi dentate gyrus, hippocampus, and subiculum. (A-D) Calretinin. Asterisks: vessels in the obliterated hippocampal fissure. Scale bars: (A) $50 \mu \mathrm{m} ;(\mathbf{B}, \mathbf{C}) 100 \mu \mathrm{m}$; (D) $25 \mu \mathrm{m}$. (A) Septal dentate gyrus and border between CA1 stratum lacunosum moleculare $(s / m)$ and subicular plexiform layer. (B)

Mid-septotemporal dentate gyrus and CA1s/m. (C) Temporal dentate gyrus and CA1s/m. (D) Calretinin+ cells in the deep pyramidal cell layer of temporal CA3. (E-L) Calbindin. Scale bars: (E,G,I-L) $50 \mu \mathrm{m} ; \mathbf{( F , H )} 250 \mu \mathrm{m}$.
(E) Heterogeneous distribution of calbindin in dentate granule cells. (F) calbindin + cells are near absent in septal CA3. (G) Temporal CA3 (H) dense band of calbindin + cells and processes at the stratum oriens/alveus border, but immunoreactive cells are otherwise near absent in CA1. (I) CA1, tangential section of stratum oriens/alveus border ( $\mathbf{J})$ Rare calbindin+ neuron deep to the CA1 pyramidal cell layer and fine plexus of fibers in the deep stratum oriens. (K) Calbindin+ deep pyramidal cells in temporal CA1. (L) CA1/subiculum border.
(Figure 5C) to fill the entire CA1slm and $S p l$ at the temporal pole.

\section{Calbindin}

Dentate gyrus. The $m l$ stains evenly light to moderate. Throughout most of the septotemporal extent of the dentate gyrus, the $g c l$ has a trilaminar appearance: moderate to strongly stained superficial and deep cells are separated by a tier of very light or unstained cells. While the deep cells form a near continuous band, lighter cells scatter between the darkly stained cells of the superficial tier (Figure 5E). A few darker cells are also found in the light middle tier. The $h p l$ appears unstained. The superficial $h p c l$ appears similar to the $m l$ and extends stained strands into the deep $\mathrm{hpcl}$ (Figure 5E) that coalesce to form the mossy fiber layer in CA3 (Figure 5F).

Hippocampus and subiculum. CA3 appears, with the exception of the mossy fiber layer, largely unstained (Figures 5F,G). Rare moderately stained cells are found at the CA3so/alveus border, which resemble those seen in CA1 (see below). Very rare $(<1$ per section) darkly stained cells are located around the $C A 3 \mathrm{sr} / \mathrm{slm}$ border. Coinciding with the end of the mossy fiber layer, the 
number of cells located at the so/alveus border increases in CA1 (Figures 5F,J). They often appear bipolar in sections cut perpendicular to the hippocampal long-axis but multipolar in sections cut parallel to the alveus (Figure 5I) and extend a network of processes that is confined to the narrow band defined by the cell bodies (Figures 5H,J). At the CA1/subiculum border, cell bodies ascend toward the CA1pcl (Figure 5L). Fine processes and a few cell bodies extend into the proximal extreme of the subiculum (Figure $5 \mathbf{L}$ ). Generally, stained cells are very rare in the remaining layers of CA1 (Figure 5H). A fine plexus of fibers is seen in the deep part of CA1so (Figure 5J). Rare strongly stained pyramidal or multipolar cells are seen in the CA1pcl (Figure 5J). Small moderately stained cells are seen rarely in the CA1sr and CA1slm. Well-stained fibers and fine particles stain the CA1slm.

Temporally, an increasing number of moderately stained cells is evenly distributed in the CA3sr and CA3slm (Figure 5G) and at the $C A 1 \mathrm{sr} / \mathrm{slm}$ border. The temporal one-third of the $C A 1 \mathrm{pcl}$ is characterized by the gradual appearance of moderate to strongly stained deep pyramidal cells. Initially, they scatter as individual cells along the deep border of the CA1pcl, but distally and further temporally, they form a continuous deep band of the CA1pcl (Figure 5K).

\section{Parvalbumin}

Dentate gyrus. Stained cells or terminal-like staining are not seen in the $m l$ (Figure 6A). Only at the border between the $m l$ and $g c l$, a dense band of fine granules extends for a short distance into the layers forming the border (Figures 6A,B). Lower density, fine granules scatter also over the remainder of the $g c l$. Pyramidal-shaped somata are found between the deepest granule cells with a preference for the suprapyramidal blade of the $g c l$ (Figures 6A,B) and extending beaded dendrites into the $m l$. The deep part of the $h p c l$ harbors a dense network of coarse and fine beaded processes, a few of which reach into the otherwise unstained $h p l$ and superficial $h p c l$. Parvalbumin+ multipolar cell bodies in the $h p c l$ are located mainly beneath the suprapyramidal $g c l$.

Septally, pyramidal-shaped cells (Figure 6B) are more common and more evenly distributed. Horizontal fibers run through the $h p l$ and superficial $h p l c$. Horizontal cells are also present. Cell bodies in the $h p c l$ become rare septally. In the temporal quarter, stained structures become rare until only even fine-grained staining remains over the $g c l$ at the temporal pole.

Hippocampus and subiculum. In CA3, most cells are either located in CA3so or associated with the CA3pcl (Figures 6C,D). In $C A 3 s o$, their dendrites form an irregular network, while most apical dendrites ascend straight through CA3sr (Figure 6D). They rarely enter $C A 3 \mathrm{slm}$. Coarse and dense terminal-like staining is seen in $C A 3 \mathrm{slm}$ and at the deep and superficial borders of $C A 3 p c l$ (Figure 6D). In CA1, cells are less frequent than in CA3. The vast majority is either associated with the $C A 1 p c l$ or found at the CA1so/alveus border. They extend beaded dendrites into the adjacent layers (Figures 6E,F), but dendrites rarely cross into the CA1slm (Figure 6E). Parvalbumin + cell morphologies at the CA1so/alveus border correspond to those of calbindin+ cells. Pyramidal-shaped cells are most common in association with the
CA1pcl, but multipolar and horizontal cells are also present. Rare cells of CA1so and CA1sr are often bipolar and oriented perpendicular to the $C A 1 p c l$ (Figure 6F). A light and fine punctuate stain fills the CA1slm. Denser and coarser particles together with fine fibers are seen throughout CA1sr and so, but concentrate above and below the CA1pcl (Figures 6E,F). Subicular parvalbumin+ cells are often pyramidal in the proximal $S c l$, but ovoid or multipolar in the distal subiculum. In both parts, they are located mainly in the deep $S c l$ (Figure 6G). Dendrites extend to the pial surface proximally only, while immunoreactive cells are more frequent distally (Figure 6G). Coarse terminal-like staining fills the deep $S p l$ and entire $S c l$ (Figures 6G,H).

No gross changes in the staining pattern are seen along the septotemporal axis of CA3. Septally, cells associated with the $C A 1 p c l$ become fewer, while terminal- and fiber-like staining is unchanged. Temporally, cells become rare in the distal subiculum (Figure 6H).

\section{Somatostatin}

Dentate gyrus. Immunoreactive cells are absent from the $m l$, $g c l$, and $h p l$. 30-50 large, bi- or multipolar cells scatter evenly throughout the superficial $h p c l$ (Figure 6I). There is a clear septotemporal low to high gradient in cell density. Temporally, cells appear smaller and scatter evenly throughout the hpcl. Septally, cell morphology remains unchanged but staining intensity decreases.

Hippocampus und subiculum. Immunoreactive cells are scattered evenly along the $C A 3 s o /$ alveus border (Figure 6J). From there, they also extend in between CA3 and its reflected blade forming part of the hpcl. They stain weaker than in the dentate gyrus and their morphology is therefore difficult to determine. Both bipolar cells and cell with a prominent apical dendrite are among them. 5-10 per section are found scattered throughout the remaining layers of CA3, with a slight preference for the CA3sr (Figure 6J). In CA1, immunoreactive cell are almost exclusively found at the CA1so/alveus border (Figure 6K). Cell density is highest in the proximal part of CA1, and many cells have a bipolar appearance. Rare cells outside this zone ( 1 or 2 per section) are often located close to the deep CA1pcl (Figure 6K). The deep band of cells follows the CA1/subiculum border to the junction between CA1pcl and $S c l$. From there, they scatter in the deep one-half of the $S c l$ without a proximal-distal gradient (Figure 6L).

Cell density increases from the septal to the temporal CA3, while it appears stable in CA1. In CA3, this increase is most pronounced in CA3so and $s r$, and it is accompanied by a dispersal of the cell band at the so/alveus border.

\section{Neurogenesis}

The appearances of PCNA+ proliferating cell, DCX+, PSANCAM+ and NeuroD+ young neurons, and apoptotic cells are illustrated in Figure 7. Both proliferating cells (Figure 7A) and young neurons (Figures 7B-D) are distributed rather evenly along the lower margin of the $\mathrm{gcl}$. Young neurons are rarely positioned further superficially than in the deep 2-3 cell tiers of the $\mathrm{gcl}$. A decline in their numbers along the septotemporal axis of the $\mathrm{gcl}$ is noticeable but not pronounced. DCX did define cell bodies and dendrites more clearly than PSA-NCAM (Figures 7B,D), while PSA-NCAM defined the axonal fields of the cells in the hilus and 

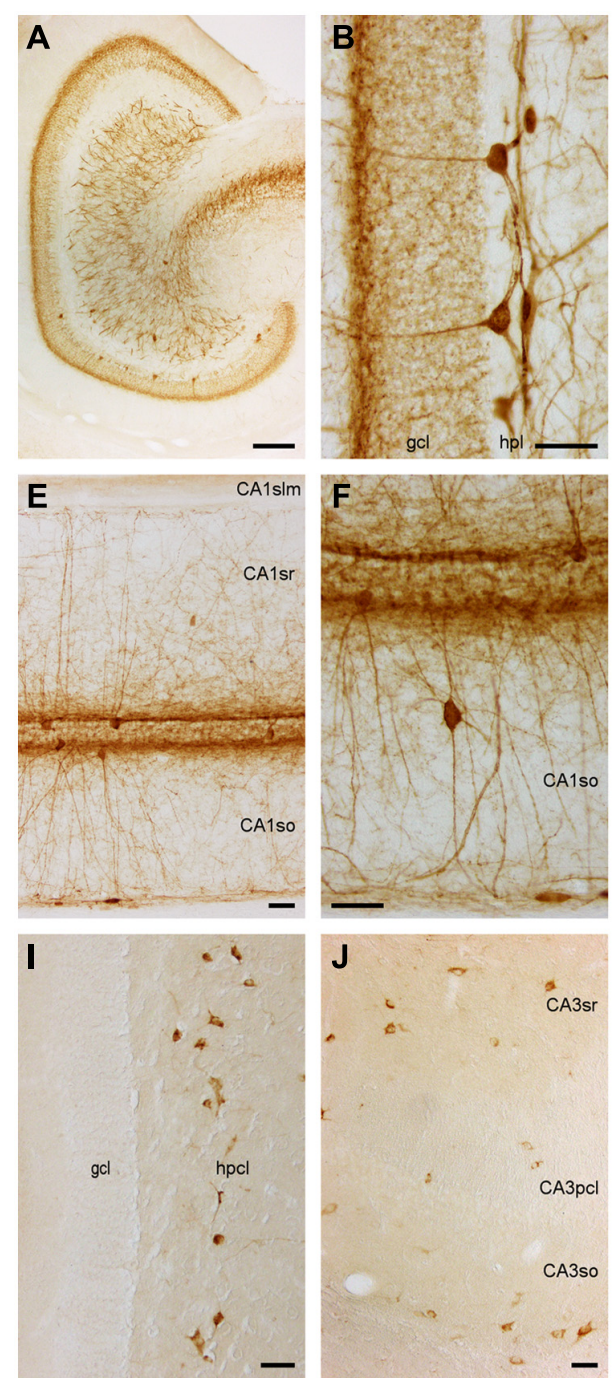

FIGURE 6 | Parvalbumin and Somatostatin in the eastern rock sengi dentate gyrus, hippocampus and subiculum. (A-H) Parvalbumin. Scale bars: (A,C,G,H) $250 \mu \mathrm{m}$; (B,D-F) $50 \mu \mathrm{m}$ (A) Mid-septotemporal dentate gyrus. (B) Septal granule cell and hilar plexiform layers. (C) Septal CA3. (D) Mid-septotemporal CA3 containing unusually many parvalbumin + cells that reflect their morphological heterogeneity. (E,F) Mid-septotemporal
CA3 better than DCX (Figures 7D,E). Based on the distribution of PSA-NCAM, the axons of young neurons are evenly distributed within the terminal fields of the mossy fibers (compare Figures $2 \mathrm{~F}$ and 7E).

Number estimates corresponding to those presented for the principal cell populations are listed in Table 4. We did not observe any gender differences between the numbers of PCNA+ cells, DCX+ young neurons and apoptotic cells with [PCNA: $F(1,9)=1.22, p=0.30$; DCX: $F(1,9)=0.24 ; p=0.64$; Apo: $F(1,9)=1.21, p=0.30$ ] or without [PCNA: $F(1,10)=0.92$, $p=0.36$; DCX: $F(1,10)=0.25, p=0.63$; Apo $F(1,10)=0.24$; $p=0.64]$ tentative age as a covariate. $\mathrm{CE}^{2} / \mathrm{CV}^{2}$ ratios were well below 0.5 , suggesting that only a very small part of the group variances originated from the estimation procedure.
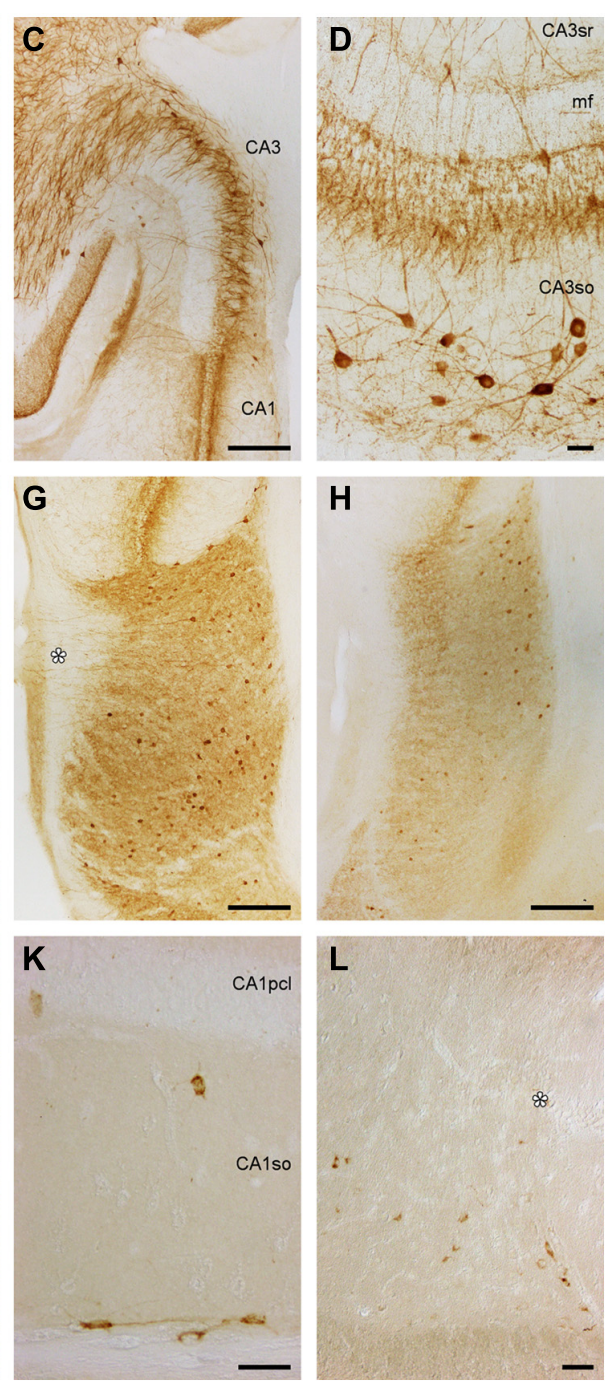

CA1. (G) Septal subiculum. Beaded dendrites reach the pial surface in the proximal subiculum only (asterisk). (H) Temporal subiculum. (I-L) Somatostatin. Scale bars: (I,J) $50 \mu \mathrm{m}$ (I) Dentate gyrus. Immunoreactive cells are only found in the hilar polymorphic cell layer. (J) CA3. (K) CA1. (L) Proximal subiculum (asterisk marks the end of the CA1 pyramidal cell layer).

The number of PCNA+ proliferating cell was highly correlated with both the numbers of DCX + young neurons $(r=0.64$, $p=0.007)$ and apoptotic cells $(r=0.72, p=0.004)$. There was no correlation between the number of DCX + young neurons and apoptotic cells $(r=0.35, p=0.13)$. No correlation was found between tentative age and the numbers of PCNA+ proliferating cell $(r=0.055, p=0.43)$ and apoptotic cells $(r=-0.15, p=0.32)$ while a trend toward a negative correlation was seen for DCX+ young neurons $(r=-0.395 p=0.10)$.

The normalized numbers of PCNA + cells in sengis fall within the range defined by all four species of murine rodents that had been captured in the same location. However, the normalized numbers of DCX + cells were lower than in three of the murine species (Figure 8). 

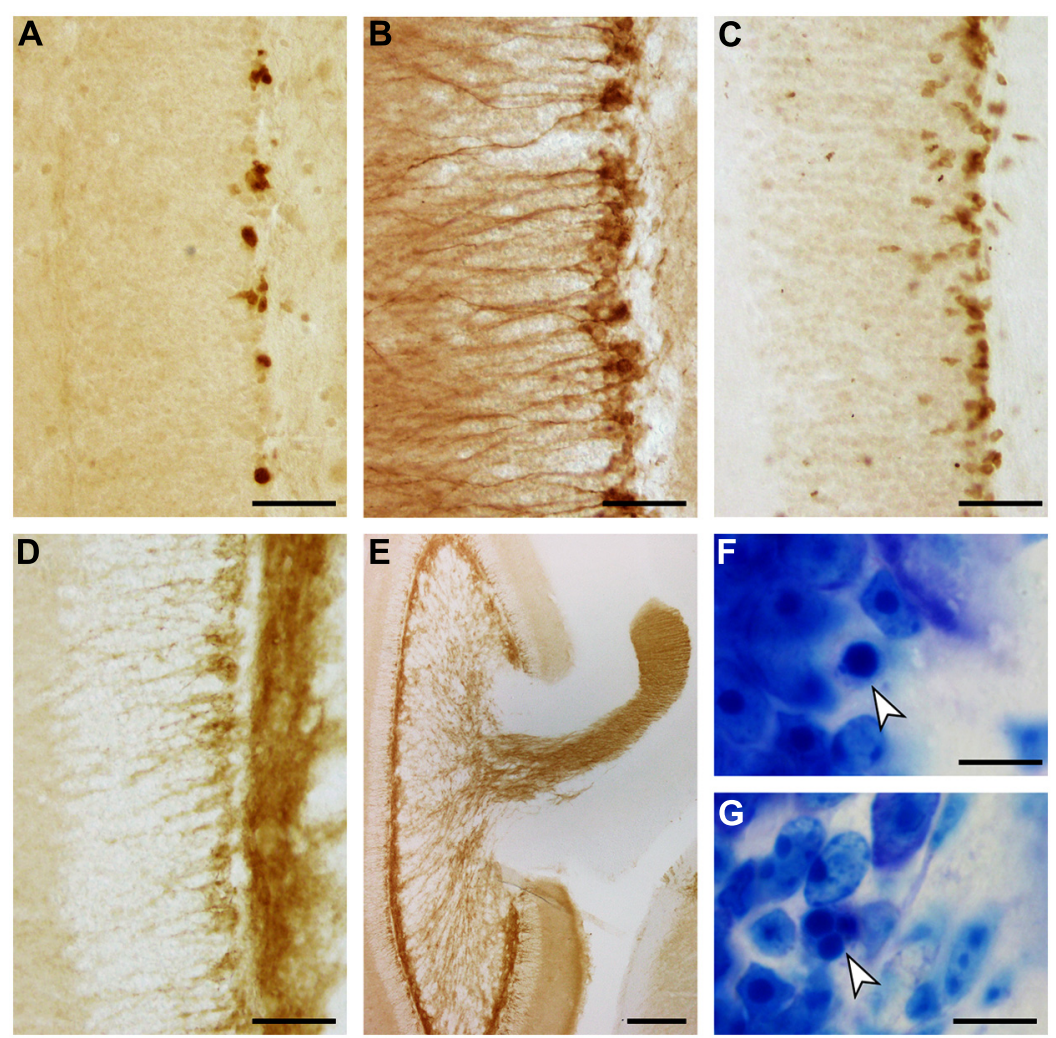

FIGURE 7 | Adult hippocampal neurogenesis in the eastern rock sengi dentate gyrus. Images were taken in the septal hippocampus corresponding to Figure 2B. (A) PCNA+ cells. (B) DCX + cells. (C) NeuroD + cells. (D)
PSA-NCAM+ cells and neuropil. (E) PSA-NCAM+ cells and mossy fiber terminal fields. (F,G) Pyknotic cells (arrows). Scale bars: (A-D) $50 \mu \mathrm{m}$; (E) $250 \mu \mathrm{m} ;(\mathbf{F}, \mathbf{G}) 10 \mu \mathrm{m}$

\section{DISCUSSION}

The eastern rock sengi hippocampus does show individual characters that associate it with any one of the phylogenetic groups that it has been related with. Their combination is, however, unique and, as will be discussed below, forms a distinct data point in the matrix of hippocampal characters that represent species with different phylogenetic and ecological backgrounds. Results will be discussed in the order in which they have been described.

\section{HIPPOCAMPAL CYTOARCHITECTURE AND CELL NUMBERS}

Cytoarchitecturally, the eastern rock sengi hippocampus may, grossly speaking, be described as having a primate like dentate gyrus and CA3, to which a CA1 and subiculum that resemble those found in the rabbit or guinea pig (Geneser-Jensen et al., 1974; Geneser, 1987a) have been added. Cell numbers also reflect the qualitative similarity of the dentate gyrus and CA3 to that of the rhesus monkey. A high degree of convergence from granule cells to CA3 pyramids is shared by the two species. Recalling early comments on the size of the sengi hippocampus, the total number of granule cells in the sengi (3.9 million unilateral, bodyweight $\sim 50 \mathrm{~g}$ ) is higher than in marmoset monkeys (3.6 million unilateral, bodyweight $\sim 250-500$ g; Kozorovitskiy et al., 2005) and more than half of that in adult rhesus monkeys (7.7 million unilateral, bodyweight $\sim 7 \mathrm{~kg}$; Keuker et al., 2003a). The large sengi dentate gyrus is not accompanied by a large entorhinal cortex (Stephan, 1961).

Comparative aspects of the junction between the dentate gyrus and CA3 have been subject of early and sustained discussions (Lorente de Nó, 1934; Rosene and van Hoesen, 1987; Keuker et al., 2003b). It is generally accepted that primates show a reflected blade of the hippocampal pyramidal cell layer, a CA4 as defined by Rosene and van Hoesen (1987), that is not found in laboratory mice and rats, in which the deep hilus forms a polymorphic cell mass connectionally and cytoarchitecturally unrelated to CA3 pyramidal cells (Blackstad, 1956; Amaral, 1978). The definition of CA4 by Rosene and van Hoesen (1987) excludes the hilar polymorphic cells that Lorente de Nó (1934) for "didactic" rather than connectional or cytoarchitectural reasons included as a second reflected blade in his definition of CA4. A reflected blade of the hippocampal pyramidal cell layer is, with minor morphological variations on the theme found in primates, present in fox (Amrein and Slomianka, 2010), pig (Holm and West, 1994), guinea pig (Geneser-Jensen, 1972), and rabbit (Geneser, 1987b) - to name but a few species. Despite the close relation between CA4 and CA3, CA4 pyramidal cells have typically been grouped with hilar polymorphic cells in quantitative studies, presumably because a reliable border between CA3 and CA4 is often easier to define than the border between the $h p c l$ and CA4. Unexpectedly, this apparently spurious assignment does result in very similar degrees 


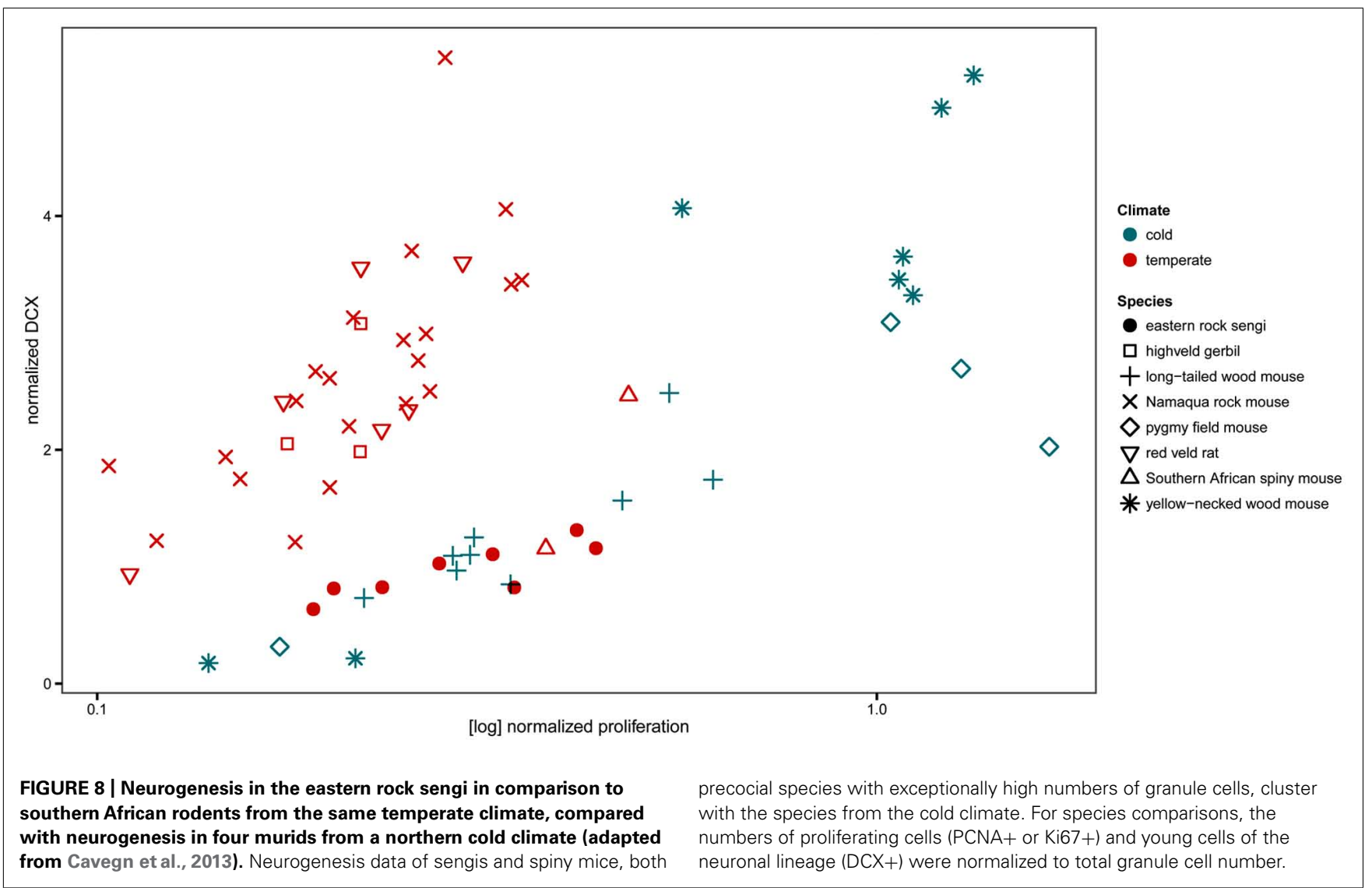

of convergence from dentate granule cells to hilar/CA4 cells in species with and without a CA4 (laboratory mouse, laboratory rat, dog, rhesus monkey, and sengi). Only pigs and humans, both with a CA4, show a much smaller convergence. In contrast, more variation is seen in the convergence from the anatomically "cleanly" defined dentate granule cells to CA3 cells. The unexpected association of rats and mice with dog, rhesus monkey and sengi may be explained by septotemporal changes in dentate histoarchitecture. An increase in the cell number of the temporal hilus (Gaarskjaer, 1978) of rats and mice that cannot be accounted for by an increase in the number of mossy cells alone (Fujise and Kosaka, 1999) and concomitant changes in the conformation of the dentate-CA3 junction (Haug, 1974) suggest that a CA4-like cell population may be present temporally. Beyond the mossy fiber projection, back projections from proximal/ventral CA3 to the dentate gyrus (Li et al., 1994; Scharfman, 2007) may create a functional link (e.g., in dentate pattern separation, Myers and Scharfman, 2011) close enough to mediate a concerted phylogenetic development of CA4 cell numbers and dentate granule cell numbers.

Although the cytoarchitecture of the sengi CA1 is strikingly different from that of primates, dog and pig, the degree of divergence from CA3 to CA1 pyramids of all these species is similar and larger than in rat, mice and tree shrew. The correspondence analysis does identify CA1 as a region particularly large in humans, but it does not group humans with rhesus monkeys, which confirms earlier observations
(Seress, 1988). Although the size of CA1 expands in primates (Stephan, 1983), this expansion does not set the rhesus monkeys apart from other taxonomic groups represented by pig and sengi.

The proximal and distal subicular divisions and their changes along the septotemporal axis in the sengi subiculum are similar to those in rats and mice, in which they correspond to subicular compartments with distinct connectional and physiological properties (O’Mara et al., 2001; Witter, 2006; Ohara etal., 2009). In sengis, subicular cell number is very small when compared to that of CA1, the main source of hippocampal subicular afferents. Extrahippocampal limbic system cell numbers are only available for two species (rats and humans) precluding an extended correspondence analysis of cell numbers. However, size indices based on volumes for the sengi retrohippocampal cortical (peri- and entorhinal cortex) and subcortical (septum) CA1 target areas are smaller than those for the hippocampus itself (Stephan, 1961), which would argue that they do not function as alternative, unusually large targets for CA1 projections. This is similar to the size relations between the entorhinal cortex and the dentate gyrus at the entrance to hippocampal circuitry and raises the question of the computational advantage of a large hippocampus when no commensurate changes are apparent in the sources and targets of hippocampal connections.

What is brought out by the comparative quantitative data is that generalized models of hippocampal function will have to be 
robust to up to fivefold differences in ratios between the numbers of interconnected cell populations. Furthermore, interspecific differences encompass opposing trends in the degrees of divergence and convergence both across the entire tri-synaptic loop as well as at specific steps along this path. Lastly, while similarities exist between sengi and taxonomically disparate groups in the quantitative composition of hippocampal principal neurons, sengis form a distinct cluster in the data space defined by quantitative relations between the major brain divisions that is clearly separated from, e.g., primates (de Winter and Oxnard, 2001; Oxnard, 2004). Similarly composed hippocampi have thus been embedded into quantitatively different higher level networks.

\section{MARKERS OF NEURONAL FUNCTION Calretinin}

Based on cellular morphology, location and staining gradients in the $c / a$-zone of the dentate $m l$, calretinin + cells in the hilus are likely to represent mossy cells with projections that ascend beyond the location of the cell body, but with only sparse projections reaching the septal pole of the dentate gyrus. Cytoarchitecturally, the cell type that is calretinin + in the temporal hilus is calretininin the septal hilus. A similar distribution of calretinin in mossy cells was seen in the mouse, hamster, gerbil, laboratory shrew, primates, and humans (Liu et al., 1996; Blasco-Ibáñez and Freund, 1997; Fujise et al., 1998; Murakawa and Kosaka, 1999; Jinno and Kosaka, 2006; Seress et al., 2008). Calretinin+ CA1 and CA3 interneurons that are present in the above mentioned species and in rat (Gulyás etal., 1992), monkey (Seress etal., 1993), and human (Nitsch and Ohm, 1995) are, with very rare exceptions, absent in the sengi. In contrast, small calretinin + cells in the sengi dentate and CA3 molecular layers are rarely seen in adult individuals of other species. Their distribution in the adult sengi and gerbil (Murakawa and Kosaka, 1999) resembles that of calretinin + Cajal-Retzius cells in the developing mouse hippocampus (Soriano et al., 1994; Berger and Alvarez, 1996; Jiang and Swann, 1997) and adult human hippocampus (Abraham and Meyer, 2003).

Calretinin+ CA3 hippocampal pyramidal cells have been reported during murine development (Jiang and Swann, 1997), but not in adult laboratory rats. A few calretinin+ proximal CA3 pyramidal cells were seen in laboratory mice (Fujise and Kosaka, 1999). They are present throughout CA3 in a subpopulation of pyramidal cells of the Guaira spiny rat (Fabene et al., 2001), and we also reported the presence of another calcium-binding protein, calbindin, in deep CA3 pyramidal cells in naked mole-rats (Slomianka et al., 2011). Lastly, calretinin is not present in cells of the deep $g c l$ or in the $h p l$ (including the subgranular zone, see discussion of neurogenesis).

\section{Calbindin in principal cells}

We recently noted a heterogeneous distribution of calbindin in the granule cells of three sympatric African murine rodent species (Cavegn et al., 2013) that in two of the species appears similar to that in the sengi, i.e., calbindin + cells in superficial and deep cells of the $g c l$ separated by a tier of very light or unstained cells. A morphological and functional heterogeneity defining a population at the superficial limit of the rat $g c l$ has also been described (Williams et al., 2007; Larimer and Strowbridge, 2010). Notably, a preferential expression of calbindin in superficial granule cells is also seen in FMR1 knockout mice (Real et al., 2011), a gene encoding FMRP (fragile mental retardation protein). A morphologically heterogeneous population of granule cells is present in the fox as well (Amrein and Slomianka, 2010). It has been suggested that connections between developmentally matched groups within the hippocampal principal cell populations form distinct information streams (Deguchi et al., 2011), and differential expressions of calcium-binding proteins add to the morphological and functional differences that may be reflections of such streams.

Superficial calbindin + CA1 pyramidal cells are found in mouse, rat, fox, and primates (reviewed in Slomianka et al., 2011). This marker is not expressed by superficial pyramids in guinea pig and rabbit and is absent in the sengi too. In mice, the condensation of pyramidal cells into a compact layer and the expression of CA1 specific markers, including calbindin, are developmentally regulated by the expression of Zbtb20 (Nielsen et al., 2007, 2010; Xie et al., 2010; Rosenthal et al., 2012). In contrast, the absence of calbindin from superficial pyramidal cells in spite of a pronounced condensation of the cell layer suggests an independent development of these characteristics in the sengi, guinea pig and rabbit CA1. Mechanisms related to age- (Poitier et al., 1994; Villa et al., 1994; de Jong et al., 1996), activity- (Lowenstein et al., 1991; Maglóczky et al., 1997), or hormone-dependent (Krugers et al., 1995; Trejo et al., 2000) changes of calbindin content in hippocampal principal cells may mediate species-specific expression patterns. Deep calbindin+ pyramidal cells are present in CA1 of fox and primates and in the distal and temporal CA1 of mouse and rat. In these species, they form the deepest tier of pyramids in a temporally and distally wide and trilaminar CA1pcl. Deep calbindin + pyramids in the sengi share the distal and temporal location, but they still form a compact band together with calbindin- superficial pyramidal cells.

\section{Calbindin in interneurons}

There is a very marked shift in the distribution of calbindin+ putative interneurons to the stratum oriens/alveus border in the sengi when compared to mouse (Jinno and Kosaka, 2006), rat (Sloviter, 1989; Tóth and Freund, 1992), dog (Hof et al., 1996), or primates (Seress et al., 1991; Sloviter et al., 1991). Cell morphologies in this zone correspond to those described in primates. The distinct plexus of fibers in the CA1slm suggest an origin from O-LM inhibitory neurons (Freund and Buzsáki, 1996; Wouterlood etal., 2001) which is supported by the appearance of the dendritic arbors of many calbindin + cells at the CA1so/alveus border. Interneurons with selective axonal projections to the CA1so have not been described (Freund and Buzsáki, 1996). Although O-LM cell axons do arborize in the CA1so, this is a minor projection compared to the CA1slm in laboratory mice and rats. Cell morphologies and location of calbindin+ cells also correspond to septally projecting type II cells of Gulyás and Freund (1996). Outside the stratum oriens/alveus border, calbindin + interneurons are rare or absent in most of the sengi dentate gyrus and hippocampus - a feature that the sengi shares 
with the Guaira spiny rat (Fabene et al., 2001). Only in temporal CA3 does their apparent number and distribution correspond to that in other species. In contrast to the dentate gyrus and hippocampus, proximal-distal and radial distributions as well as septotemporal changes of the distributions of calbindin + cells in the subiculum corresponds well to those of mice (Fujise et al., 1995).

\section{Parvalbumin}

The laminar distribution of parvalbumin in sengi interneurons corresponds to that in the dentate gyrus and hippocampus of rat (Nomura et al., 1997), mouse (Jinno and Kosaka, 2006), dog (Hof etal., 1996), tree shrew (Keuker etal., 2003b), or monkey (Seress et al., 1991). They still appear, to us, less frequent than in these species, although the difference is much less pronounced that that for calbindin and calretinin and would require robust quantitation to draw firm conclusions. Much of the dense parvalbumin + terminal staining reflects, like in other species, the distribution of axons of parvalbumin + chandelier and pyramidal basket cells (Freund and Buzsáki, 1996; Sik et al., 1997). The distribution of parvalbumin in the subiculum follows, like that of calbindin, closely the pattern described in mice (Fujise et al., 1995). While parvalbumin appears more resilient to phylogenetic change than calretinin or calbindin in eutherian mammals, the distribution is restricted to fewer cell types in prototherian echidna (Hassiotis et al., 2005).

\section{Somatostatin}

The cellular distribution of somatostatin in the sengi hippocampus is similar to that of the rat and mouse (Köhler and ChanPalay, 1982; Bakst et al., 1986; Buckmaster et al., 1994), guinea pig and rabbit (Buckmaster et al., 1994), pig (Holm et al., 1992), and human (Chan-Palay, 1987), although neurons are generally more common in the stratum oriens of these species than in the sengi. In the dentate gyrus, they are likely to correspond to cells with axonal arbors in the perforant path zones (HIPP cells, Freund and Buzsáki, 1996). We have not been able to show a plexus of somatostatin containing fibers that is present in the dentate $m l$ or CA1slm of mouse and rabbit (Buckmaster et al., 1994). Somatostatin containing cells at the so/alveus border of CA3 and CA1 are likely to represent LM- and O-LM neurons, respectively (Freund and Buzsáki, 1996). They have also been found to co-localize with calbindin (Wouterlood et al., 2001).

\section{NEUROGENESIS}

Home ranges of eastern rock sengi females are typically smaller than those of males (Ribble and Perrin, 2005). In that AHN did not differ between males and females, spatial requirements associated with the absolute size of the home range are unlikely to be related to AHN. We have recently shown (Cavegn et al., 2013) that Muridae trapped in the same habitat (Köppen-Geiger climate classification Cwa, Peel et al., 2007) as the sengis did differ in proliferation (lower) and neuronal differentiation (higher) from Muridae that were collected in a different, European habitat (Köppen-Geiger climate classification Dfb). This difference was consistent across multiple species that belonged to different taxonomic subunits and that also differed in, e.g., habitat use and social organization. The sengi does not group with most of the sympatric Muridae, but instead associates with European Muridae. Only southern African spiny mice showed AHN related cell counts close to those of the sengi. Spiny mice and sengi share the traits of exceptionally high numbers of granule cells (Cavegn et al., 2013) and precociality. Current data cannot address how much of the observed variation in AHN of sengis and spiny mice could be related to phylogeny, to anatomical context of AHN or to demands on hippocampal information processing mediated by the young neurons that relate to their ecology. Also, the regulation of markers that are expressed during specific stages of neuronal differentiation differs in the sengi from that seen in other species. Calretinin is expressed during the late post-mitotic differentiation of granule cells in mice (Brandt et al., 2003; Kempermann et al., 2004). Calretinin + cells are not seen in numbers or morphologies that correspond to those of DCX+ or PSA-NCAM+ cells in the dentate subgranular zone and deep $g c l$. The expression of calretinin is apparently not part of neuronal differentiation in the sengi.

Similar size progressions of the hippocampus and dentate gyrus in sengis and primates do not relate to AHN in similar ways. AHN is not only low in primates, but also characterized by an extended period of differentiation of the newly formed cells of neuronal lineage (Ngwenya et al., 2006; Kohler et al., 2011). Both the numbers of proliferating and differentiating cells and their ratio in the sengi fall within the ranges seen in murine rodents. Clearly, a large hippocampus relative to body size does not necessarily obviate AHN.

\section{CONCLUSION}

The distinct positions of species, including a clustering of mice and rats, in the correspondence analysis point toward the existence of distinct patterns of quantitative relations between hippocampal principal cell populations. If these patterns relate to the phylogenetic history of the species and/or to demands on hippocampal information processing related to species ecology remains an open question. de Winter and Oxnard (2001) showed that quantitative relations between even major brain divisions could group species by lifestyle despite different phylogenetic histories. This is likely to be more common as anatomical resolution and, thereby, functional specificity increases. In our data, this is brought out by the separation of the human and rhesus monkey hippocampus and the association of rhesus monkey, pig, and sengi despite their disparate phylogenetic histories. The scarcity of calbindin + and calretinin + interneurons in, in particular, CA1 of the sengi hippocampus represent an additional tier of specialization that separates the sengi from species which appear similar based in quantitative relations between principal cells.

In the context of sengi hippocampal specializations, "normal, mouse-like" quantitative data on sengi AHN are an almost surprising relief. However, the sengi affiliates with our sample of European mice instead of most of the sympatric mouse species, which again raises the question if differences relate to anatomical context and/or selective pressures on AHN related to sengi ecology. 
The most intriguing question remaining is why the sengi hippocampus is so large when the cortical and subcortical areas that are hippocampal sources of afferents and targets of efferents are not. We pointed out that generalized models of hippocampal function need to be robust to large differences in convergence and divergence along the intrahippocampal pathways. In addition, such models may have to endow large hippocampi with intrinsic computational abilities which provide selective advantages that,

\section{REFERENCES}

Abraham, H., and Meyer, G. (2003). Reelin-expressing neurons in the postnatal and adult human hippocampal formation. Hippocampus 13,715-727. doi: 10.1002/hipo.10125 Amaral, D. G. (1978). A Golgi study of cell types in the hilar region of the hippocampus in the rat. $J$. Comp. Neurol. 182, 851-914. doi: 10.1002/cne.901820508

Amrein, I., Isler, K., and Lipp, H.-P. (2011). Comparing adult hippocampal neurogenesis in mammalian species and orders: influence of chronological age and life history stage. Eur. J. Neurosci. 34, 978987. doi: 10.1111/j.1460-9568.2011. 07804.x

Amrein, I., and Slomianka, L. (2010). A morphologically distinct granule cell type in the dentate gyrus of the red fox correlates with adult hippocampal neurogenesis. Brain Res. 1328, 12-24. doi: 10.1016/j.brainres.2010.02.075

Amrein, I., Slomianka, L., and Lipp, H.-P. (2004a). Granule cell number, cell death and cell proliferation in the dentate gyrus of wild-living rodents. Eur. J. Neurosci. 20, 3342-3350. doi: 10.1111/j.1460-9568.2004.03795.x

Amrein, I., Slomianka, L., Poletaeva, I. I., Bologova, N. V., and Lipp, H.-P. (2004b). Marked species and age-dependent differences in cell proliferation and neurogenesis in the hippocampus of wild-living rodents. Hippocampus 14, 1000-1010. doi: 10.1002/hipo.20018

Bakst, I., Avendano, C., Morrison, J. H., and Amaral, D. G. (1986). An experimental analysis of the origins of somatostatin-like immunoreactivity in the dentate gyrus of the rat. $J$. Neurosci. 6, 1452-1462.

Berger, B., and Alvarez, C. (1996). Neurochemical development of the hippocampal region in the fetal Rhesus monkey. III: calbindinD28k, calretinin and parvalbumin with special mention of CajalRetzius cells and the retrosplenial cortex. J. Comp. Neurol. 366, 674-699. doi: 10.1002/(SICI) 10969861(19960318)366:4<674::AID-C $\mathrm{NE} 8>3.0 . \mathrm{CO} ; 2-1$
Blackstad, T. W. (1956). Commissural connections of the hippocampal region in the rat, with special reference to their mode of termination. J. Comp. Neurol. 105, 417-537. doi: 10.1002/cne.901050305

Blasco-Ibáñez, J. M., and Freund, T. F. (1997). Distribution, ultrastructure, and connectivity of calretininimmunoreactive mossy cells of the mouse dentate gyrus. Hippocampus 7, 307-320. doi: 10.1002/(SICI)10981063(1997)7:3 <307::AID-HIPO6> 3.0.CO;2-H

Brandt, M. D., Jessberger, S., Steiner, B., Kronenberg, G., Reuter, K., BickSander, A., et al. (2003). Transient calretinin expression defines early postmitotic step of neuronal differentiation in adult hippocampal neurogenesis of mice. Mol. Cell. Neurosci. 24, 603-613. doi: 10.1016/S10447431(03)00207-0

Buckmaster, P. S., Kunkel, D. D., Robbins, R. J., and Schwartzkroin, P. A. (1994). Somatostatinimmunoreactivity in the hippocampus of mouse, rat, guinea pig, and rabbit. Hippocampus 4, 167-180. doi: 10.1002/hipo.450040207

Cavegn, N., Van Dijk, R. M., Menges, D., Brettschneider, H., Phalanndwa, M., Chimimba, C. T., et al. (2013). Habitat-specific shaping of proliferation and neuronal differentiation in adult hippocampal neurogenesis of wild rodents. Front. Neurosci. 7:59. doi: 10.3389/fnins.2013.00059

Chan-Palay, V. (1987). Somatostatin immunoreactive neurons in the human hippocampus and cortex shown by immunogold/silver intensification on vibratome sections: coexistence with neuropeptide $Y$ neurons, and effects in Alzheimer-type dementia. J. Comp. Neurol. 260, 201-223. doi: $10.1002 / \mathrm{cne} .902600205$

Culhane, A. C., Thioulouse, J., Perriere, G., and Higgins, D. G. (2005). MADE4: an R package for multivariate analysis of gene expression data. Bioinformatics 21, 2789-2790. doi: 10.1093/bioinformatics/bti394

Danscher, G., and Zimmer, J. (1978). An improved Timm sulphide silver method for light and electron microscopic localization of heavy metals in

based on our current knowledge, are independent of the number of available input and output channels.

\section{ACKNOWLEDGMENTS}

We thank Inger Drescher and Rosmarie Lang for expert technical assistance in this project. Funding for this work was given by the Swiss-South Africa Joint Research Project JRP 09, and the Swiss National Science Foundation Grant Nr 31003A_141244/1.

biological tissues. Histochemistry 55, 27-40. doi: 10.1007/BF00496691

Deguchi, Y., Donato, F., Galimberti, I., Cabuy, E., and Caroni, P. (2011). Temporally matched subpopulations of selectively interconnected principal neurons in the hippocampus. Nat. Neurosci. 14, 495-504. doi: $10.1038 / \mathrm{nn} .2768$

de Jong, G. I., Naber, P. A., Van Der Zee, E. A., Thompson, L. T., Disterhoft, J. F., and Luiten, P. G. M. (1996). Age-related loss of calcium binding proteins in rabbit hippocampus. Neurobiol. Aging 17, 459-465. doi: 10.1016/0197-4580(96)00030-9

Dengler-Crish, C. M., Crish, S. D., O'riain, J., and Catania, K. C. (2006). Organization of the somatosensory cortex in elephant shrews (E. edwardii). Anat. Rec. 288, 859866. doi: 10.1002/ar.a.20357

de Winter, W., and Oxnard, C. E. (2001). Evolutionary radiations and convergences in the structural organization of mammalian brains. Nature 409 , 710-714. doi: 10.1038/35055547

Dorph-Petersen, K.-A., Nyengaard, J. R., and Gundersen, H. J. G. (2001). Tissue shrinkage and unbiased stereological estimation of particle number and size. J Microscopy 204, 232-246. doi: 10.1046/j.13652818.2001.00958.x

Eriksson, P. S., Perfilieva, E., BjörkEriksson, T., Alborn, A. M., Nordborg, C., Peterson, D. A., et al. (1998). Neurogenesis in the adult human hippocampus. Nat. Med. 4, 13131317. doi: $10.1038 / 3305$

Fabene, P. F., Correia, L., Carvalho, R. A., Cavalheiro, E. A., and Bentivoglio, M. (2001). The spiny rat Proechimys guyannensis as a model of resistance to epilepsy: chemical characterization of hippocampal cell populations and pilocarpine-induced changes. Neuroscience 104, 9791002. doi: $10.1016 / S 0306-4522(01)$ 00138-5

Fabricius, K., Wörtwein, G., and Pakkenberg, B. (2008). The impact of maternal separation on adult mouse behaviour and on the total neuron number in the mouse hippocampus. Brain Struct. Funct. 212, 403-416. doi: 10.1007/s00429-007-0169-6
Fitting, S., Booze, R. M., Hasselrot, U., and Mactutus, C. F. (2010). Dose-dependent long-term effects of tat in the rat hippocampal formation: a design-based stereological study. Hippocampus 20, 469-480. doi: 10.1002/hipo. 20648

Freund, T. F., and Buzsáki, G. (1996). Interneurons of the hippocampus. Hippocampus 6, 347-470. doi: 10.1002/(SICI) 10981063(1996)6:4<347::AID-HIPOl> 3.0.CO;2-I

Fujise, N., Hunziker, W., Heizmann, C. W., and Kosaka, T. (1995). Distribution of the calcium binding proteins calbindin D-28k and parvalbumin, in the subicular complex of the adult mouse. Neurosci. Res. 22, 89-107. doi: 10.1016/0168-0102(95)00882-T

Fujise, N., and Kosaka, T. (1999). Mossy cells in the mouse dentate gyrus: identification in the dorsal hilus and their distribution along the dorsoventral axis. Brain Res. 816, 500-511. doi: 10.1016/S00068993(98)01202-5

Fujise, N., Liu, Y., Hori, N., and Kosaka, T. (1998). Distribution of calretinin immunoreactivity in the mouse dentate gyrus: II. mossy cells, with special reference to their dorsoventral difference in calretinin immunoreactivity. Neuroscience 82, 181-200. doi: 10.1016/S0306-4522(97)00261-3

Gaarskjaer, F. B. (1978). Organization of the mossy fiber system of the rat studied in extended hippocampi I. terminal area related to the number of granule and pyramidal cells. J. Comp. Neurol. 178, 49-72. doi: 10.1002/cne.901780104

Gannon, W. L., Sikes, R. S., and the animal care and use committee of the American Society of Mammalogists. (2007). Guidelines for the capture, handling, and care of mammals as approved by the American Society of Mammalogists. J. Mammal. 88, 809-823. doi: 10.1644/06-MAMMF-185R1.1

Geneser, F. A. (1987a). Distribution of acetylcholinesterase in the hippocampal region of the rabbit: II. subiculum and hippocampus. $J$. Comp. Neurol. 262, 90-104. doi: 10.1002/cne.902620108 
Geneser, F. A. (1987b). Distribution of acetylcholinesterase in the hippocampal region of the rabbit: III. the dentate area. J. Comp. Neurol. 262, 594-606. doi: 10.1002/cne. 902620411

Geneser-Jensen, F. A. (1972). Distribution of acetyl cholinesterase in the hippocampal region of the guinea pig. III. The dentate area. Z. Zellforsch. Mikrosk. Anat. 131, 481-495. doi: 10.1007/BF00306966

Geneser-Jensen, F. A., Haug, F. M., and Danscher, G. (1974). Distribution of heavy metals in the hippocampal region of the guinea pig: a light microscope study with Timm's sulfide silver method. Z. Zellforsch. Mikrosk. Anat. 147, 441-478.

Gulyás, A. I., and Freund, T. F. (1996). Pyramidal cells are the primary targets of calbindin D28kimmunoreactive interneurons in the hippocampus. Hippocampus 6, 525-534. doi: 10.1002/(SICI)10981063(1996)6:5<525::AID-HIPO5> 3.0.CO;2-H

Gulyás, A. I., Miettinen, R., Jacobowitz, D. M., and Freund, T. F. (1992). Calretinin is present in non-pyramidal cells of the rat hippocampus - I. a new type of neuron specifically associated with the mossy fibre system. Neuroscience 48, 1-27. doi: 10.1016/03064522(92)90334-X

Gundersen, H. J. G., Jensen, E. B. V., Kieu, K., and Nielsen, J. (1999). The efficiency of systematic sampling in stereology - reconsidered. J Microsc. 193, 199-211. doi: 10.1046/j.13652818.1999.00457.x

Harding, A. J., Halliday, G. M., and Kril, J. J. (1998). Variation in hippocampal neuron number with age and brain volume. Cereb. Cortex 8, 710-718. doi: 10.1093/cercor/8.8.710

Hassiotis, M., Paxinos, G., and Ashwell, K. W. S. (2005). Cyto- and chemoarchitecture of the cerebral cortex of an echidna (Tachyglossus aculeatus). II. Laminar organization and synaptic density. J. Comp. Neurol. 482, 94-122. doi: 10.1002/cne. 20353

Haug, F.-M. S. (1974). Light microscopical mapping of the hippocampal region, the pyriform cortex and the corticomedial amygdaloid nuclei of the rat with Timm's sulphide silver method I. Area dentata, hippocampus and subiculum. Z. Anat. Entwicklungsgesch. 145, 1-27.

Hof, P. R., Rosenthal, R. E., and Fiskum, G. (1996). Distribution of neurofilament protein and calciumbinding proteins parvalbumin, calbindin, and calretinin in the canine hippocampus. J. Chem. Neuroanat.
11,1-12. doi: 10.1016/0891-0618(96) 00117-112

Holm, I. E., Geneser, F. A., and Zimmer, J. (1992). Somatostatin- and neuropeptide Y-like immunoreactivity in the dentate area, hippocampus and subiculum of the domestic pig. J. Comp. Neurol. 322, 390-408. doi: $10.1002 /$ cne. 903220308

Holm, I. E., and West, M. J. (1994). Hippocampus of the domestic pig: a stereological study of subdivisional volumes and neuron numbers. Hippocampus 4, 115-126. doi: 10.1002/hipo.450040112

Holroyd, P. A., and Mussell, J. C. (2005). "Macroscelidae and tubulidentata," in The Rise of Placental Mammals. Origins and Relations of the Major Extant Clades, eds K. D. Rose and J. D. Archibald (Baltimore: Johns Hopkins University Press), 71-83.

Hosseini-Sharifabad, M., and Nyengaard, J. R. (2007). Design-based estimation of neuronal number and individual neuronal volume in the rat hippocampus. J. Neurosci. Methods 162, 206-214. doi: 10.1016/j.jneumeth.2007.01.009

Iñiguez, C., Gayoso, M. J., and Carreres, J. (1985). A versatile and simple method for staining nervous tissue using Giemsa dye. J. Neurosci. Methods 13, 77-86. doi: 10.1016/01650270(85)90045-7

Jabès, A., Banta Lavenex, P., Amaral, D. G., and Lavenex, P. (2010). Quantitative analysis of postnatal neurogenesis and neuron number in the macaque monkey dentate gyrus. Eur. J. Neurosci. 31, 273-285. doi: 10.1111/j.1460-9568.2009.07061.x

Jiang, M., and Swann, J. W. (1997). Expression of calretinin in diverse neuronal populations during development of rat hippocampus. Neuroscience 81, 1137-1154. doi: 10.1016/S0306-4522(97)00231-5

Jinno, S., and Kosaka, T. (2006). Cellular architecture of the mouse hippocampus: a quantitative aspect of chemically defined GABAergic neurons with stereology. $\mathrm{Neu}$ rosci. Res. 56, 229-245. doi: 10.1016/j.neures.2006.07.007

Johnson, J. I., Switzer, R. C., and Kirsch, J. A. W. (1982). Phylogeny through brain traits: the distribution of categorizing characters in contemporary mammals. Brain Behav. Evol. 20, 97-117. doi: 10.1159/ 000121584

Kempermann, G., Jessberger, S., Steiner, B., and Kronenberg, G. (2004). Milestones of neuronal development in the adult hippocampus. Trends Neurosci. 27, 447-452. doi: 10.1016/j.tins.2004.05.013
Keuker, J. I. H., De Biurrun, G. Luiten, P. G. M., and Fuchs, E. (2004). Preservation of hippocampal neuron numbers and hippocampal subfield volumes in behaviorally characterized aged tree shrews. J. Comp. Neurol. 468, 509-517. doi: 10.1002/cne.10996

Keuker, J. I. H., Luiten, P. G. M., and Fuchs, E. (2003a). Preservation of hippocampal neuron numbers in aged rhesus monkeys. Neurobiol. Aging 24, 157-163. doi: 10. 1016/S0197-4580(02)00062-63

Keuker, J. I. H., Rochford, C. D. P., Witter, M. P., and Fuchs, E. (2003b). A cytoarchitectonic study of the hippocampal formation of the tree shrew (Tupaia belangeri). J. Chem. Neuroanat. 26, 1-15. doi: 10.1016/S08910618(03)00030-39

Kirsch, J. A. W., and Johnson, J. I. (1983). Phylogeny through brain traits: trees generated by neural characters. Brain Behav. Evol. 22, 60-69. doi: 10.1159/000121507

Köhler, C., and Chan-Palay, V. (1982). Somatostatin-like immunoreactive neurons in the hippocampus: an immunocytochemical study in the rat. Neurosci. Lett. 34, 259-264. doi: 10.1016/0304-3940(82)9018590189

Kohler, S. J., Williams, N. I., Stanton, G. B., Cameron, J. L., and Greenough, W. T. (2011). Maturation time of new granule cells in the dentate gyrus of adult macaque monkeys exceeds six months. Proc. Natl. Acad. Sci. U.S.A. 108, 10326-10331. doi: $10.1073 /$ pnas. 1017099108

Korbo, L., Amrein, I., Lipp, H.-P., Wolfer, D., Regeur, L., Oster, S. et al. (2003). No evidence for loss of hippocampal neurons in nonAlzheimer dementia patients. Acta Neurol. Scand. 109, 132-139. doi: 10.1034/j.1600-0404.2003.00182.x

Kornack, D. R., and Rakic, P. (1999). Continuation of neurogenesis in the hippocampus of the adult macaque monkey. Proc. Natl. Acad. Sci. U.S.A. 96, 5768-5773. doi: 10.1073/pnas.96.10.5768

Kozorovitskiy, Y., Gross, C. G., Kopil, C., Battaglia, L., Mcbreen, M., Stranahan, A. M., et al. (2005). Experience induces structural and biochemical changes in the adult primate brain. Proc. Natl. Acad. Sci. U.S.A. 102, 17478-17482. doi: 10.1073/pnas.0508817102

Krugers, H. J., Medema, R. M., Postema, F., and Korf, J. (1995). Regionspecific alterations of calbindin-D28k immunoreactivity in the rat hippocampus following adrenalectomy and corticosterone treatment. Brain
Res. 696, 89-96. doi: 10.1016/0006 8993(95)00783-M

Larimer, P., and Strowbridge, B. W. (2010). Representing information in cell assemblies: persistent activity mediated by semilunar granule cells. Nat. Neurosci. 13, 213-222. doi: 10.1038/nn.2458

Le Gros Clark, W. E. (1928). On the brain of the Macroscelididae (Macroscelides and Elephantulus). J. Anat. 62, 245-275.

Li, X. G., Somogyi, P., Ylinen, A., and Buzsáki, G. (1994). The hippocampal CA3 network: an in vivo intracellular labeling study. $J$. Comp. Neurol. 339, 181-208. doi: 10.1002/cne.903390204

Liu, Y., Fujise, N., and Kosaka, T. (1996). Distribution of calretinin in the mouse dentate gyrus I. general description. Exp. Brain Res. 108, 389-403. doi: 10.1007/BF00227262

Lorente de Nó, R. (1934). Studies on the structure of the cerebral cortex II. continuation of the study of the Ammonic system. J. Psychol. Neurol. 46, 113-177.

Lowenstein, D. H., Miles, M. F., Hatam, F., and McCabe, T. (1991). Up regulation of calbindin-D28K mRNA in the rat hippocampus following focal stimulation of the perforant path. Neuron 6, 627-633. doi: 10.1016/0896-6273(91)90065-8

Maglóczky, Z. S., Halász, P., Vajda, J., Czirják, S., and Freund, T. F. (1997). Loss of calbindin-D28K immunoreactivity from dentate granule cells in human temporal lobe epilepsy. Neuroscience 76, 377-385. doi: 10.1016/S0306-4522(96)00440-X

Marlatt, M. W., Philippens, I., Manders, E., Czéh, B., Joels, M., Krugers, H., et al. (2011). Distinct structural plasticity in the hippocampus and amygdala of the middle-aged common marmoset (Callithrix jacchus). Exp. Neurol. 230, 291-301. doi: 10.1016/j.expneurol.2011.05.008

Michaux, J., Reyes, A., and Catzeflis, F. (2002). Evolutionary history of the most speciose mammals: molecular phylogeny of muroid rodents. Mol. Biol. Evol. 18, 2017-2031.

Murakawa, R., and Kosaka, T. (1999). Diversity of the calretinin immunoreactivity in the dentate gyrus of gerbils, hamsters, giunea pigs and laboratory shrews. J. Comp. Neurol. 411, 413-430. doi: 10.1002/(SICI)10969861(19990830)411:3<413::AID-C $\mathrm{NE} 5>3.0 . \mathrm{CO} ; 2-\mathrm{Q}$

Myers, C. E., and Scharfman, H. E. (2011). Pattern separation in the dentate gyrus: a role for the CA3 backprojection. Hippocampus 21, 1190-1215. doi: 10.1002/hipo. 20828 
Ngwenya, L. B., Peters, A., and Rosene, D. L. (2006). Maturational sequence of newly generated neurons in the dentate gyrus of the young adult rhesus monkey. J. Comp. Neurol. 498, 204-216. doi: 10.1002/cne.21045

Nielsen, J. V., Blom, J. B., Noraberg, J., and Jensen, N. A. (2010). Zbtb20-induced CA1 pyramidal neuron development and area enlargement in the cerebral midline cortex of mice. Cereb. Cortex 20, 1904-1914. doi: 10.1093/cercor/bhp261

Nielsen, J. V., Nielsen, F. H., Ismail, R., Noraberg, J., and Jensen, N. A. (2007). Hippocampus-like corticoneurogenesis induced by two isoforms of the BTB-zinc finger gene Zbtb20 in mice. Development 134, 1133-1140. doi: 10.1242/dev.000265

Nitsch, R., and Ohm, T. G. (1995). Calretinin immunoreactive structures in the human hippocampal formation. J. Comp. Neurol. 360, 475-487. doi: 10.1002/cne.903600309

Nomura, T., Fukuda, T., Aika, Y., Heizmann, C. W., Emson, P. C., Kobayashi, T., et al. (1997). Distribution of nonprincipal neurons in the rat hippocampus, with special reference to their dorsoventral difference. Brain Res. 751, 64-80. doi: 10.1016/S0006-8993(96)01395-1399

Ohara, S., Inoue, K., Yamada, M., Yamawaki, T., Koganezawa, N., Tsutsui, K., et al. (2009). Dual transneuronal tracing in the rat entorhinal-hippocampal circuit by intracerebral injection of recombinant rabies virus vectors. Front. Neuroanat. 3:1. doi: 10.3389/ neuro.05.001.2009

O’Mara, S. M., Commins, S., Anderson, M., and Gigg, J. (2001). The subiculum: a review of form, physiology and function. Prog. Neurobiol. $64,129-155$. doi: 10.1016/S03010082(00)00054-X

Oxnard, C. E. (2004). Brain evolution: mammals, primates, chimpanzees, and humans. J. Primatol. 25, 1127-1158. doi: 10.1023/ B:IJOP.0000043355.96393.8b

Patzke, N., Kaswera, C., Gilissen, E., Ihunwo, A. O., and Manger, P. R. (2013). Adult neurogenesis in a giant otter shrew (Potamogale velox). Neuroscience 238, 270-279. doi: 10.1016/j.neuroscience.2013.02.025

Peel, M. C., Finlayson, B. L., and Mcmahon, T. A. (2007). Updated world map of the Köppen-Geiger climate classification. Hydrol. Earth Syst. Sci. 11, 1633-1644.

Pieters, R. P., Gravett, N., Fuxe, K., and Manger, P. R. (2010). Nuclear organization of cholinergic, putative catecholaminergic and serotonergic nuclei in the brain of the eastern rock elephant shrew, Elephantulus myurus. J. Chem. Neuroanat. 39, 175-188. doi: 10.1016/j.jchemneu.2010.01.001

Poitier, B., Krzywkowski, P., Lamour, Y., and Dutar, P. (1994). Loss of calbindin-immunoreactivity in CA1 hippocampal stratum radiatum and stratum lacunosum-moleculare interneurons in the aged rat. Brain Res. 661, 181-188. doi: 10.1016/00068993(94)91195-91199

Rathbun, G. B. (2005). “Macroscelidea," in The Mammals of the Southern African Subregion, 3rd Edn, eds J. D. Skinner and C. T. Chimimba (Cape Town: Cambridge University Press), 22-34.

Rathbun, G. B. (2009). Why is there discordant diversity in sengi (Mammalia: Afrotheria: Macroscelidea) taxonomy and ecology. Afr. J. Ecol. 47, 1-13. doi: 10.1111/j.13652028.2009.01102.x

Real, M. A., Simón, P., Heredia, R., De Diego, Y., and Guirado, S. (2011). Phenotypic changes in calbindin D28K immunoreactivity in the hippocampus of Fmr1 knockout mice. J. Comp. Neurol. 519, 26222636. doi: 10.1002/cne. 22643

Ribble, D. O., and Perrin, F. (2005). Social organization of the Eastern Rock Elephant-shrew (Elephantulus myurus): the evidence for mate guarding. Belg. J. Zool. 135(Suppl.), 167-173.

Rosene, D. L., and van Hoesen, G. W. (1987). "The hippocampal formation of the primate brain. A review of some comparative aspects of cytoarchitecture and connections," in Cerebral Cortex, eds E. G. Jones and A. Peters (New York: Plenum), 345-456. Rosenthal, E. H., Tonchev, A. B., Stoykova, A., and Chowdhury, K. (2012). Regulation of archicortical arealization by the transcription factor Zbtb20. Hippocampus 22, 21442156. doi: 10.1002/hipo.22035

Sanides, D., and Sanides, F. (1974). A comparative Golgi study of the neocortex of insectivores and rodents. $Z$. mikrosk. Anat. Forsch. 88, 957-977.

Scharfman, H. E. (2007). The CA3 "backprojection" to the dentate gyrus. Prog. Brain Res. 163, 627. doi: 10.1016/S0079-6123(07)63034-9

Seress, L. (1988). Interspecies comparison of the hippocampal formation shows increased emphasis on the regio superior in the Ammon's horn of the human brain. J. Hirnforsch. 29, 335-340.

Seress, L., Ábrahám, H., Czéh, B., Fuchs, E., and Léránth, C. (2008). Calretinin expression in hilar mossy cells of the hippocampal dentate gyrus of nonhuman primates and humans. Hippocampus 18, 425-434. doi: 10.1002/hipo.20403

Seress, L., Gulyás, A. I., and Freund, T. F. (1991). Parvalbuminand calbindin D28k-immunoreactive neurons in the hippocampal formation of the macaque monkey. $J$. Comp. Neurol. 313, 162-177. doi: $10.1002 / \mathrm{cne} .903130112$

Seress, L., Nitsch, R., and Leranth, C. (1993). Calretinin immunoreactivity in the monkey hippocampal formation - I. light and electron microscopic characteristics and co-localization with other calcium-binding proteins. Neuroscience 55, 775-796. doi: 10.1016/ 0306-4522(93)90441-H

Sherwood, C. C., Stimpson, C. D. Butti, C., Bonar, C. J., Newton, A. L., Allman, J. M., et al. (2009). Neocortical neuron types in Xenarthra and Afrotheria: implications for brain evolution in mammals. Brain Struct. Funct. 213, 301-328. doi: 10.1007/s00429-008-0198-9

Sik, A., Penttonen, M., and Buzsáki, G. (1997). Interneurons in the hippocampal dentate gyrus: an in vivo intracellular study. Eur. J. Neurosci. 9, 573-588. doi: 10.1111/j.1460 9568.1997.tb01634.x

Simic, G., Kostovic, I., Winblad, B., and Bogdanovic, N. (1997). Volume and number of neurons of the human hippocampal formation in normal aging and Alzheimer's disease. J. Comp. Neurol. 379, 482-494. doi: 10.1002/(SICI)10969861(19970324)379:4<482::AID-C $\mathrm{NE} 2>3.0 . \mathrm{CO} ; 2-\mathrm{Z}$

Siwak-Tapp, C. T., Head, E., Muggenburg, B. A., Milgram, N. W., and Cotman, C. W. (2008). Region specific neuron loss in the aged canine hippocampus is reduced by enrichment. Neurobiol. Aging 29, 39-50. doi: 10.1016/j.neurobiolaging.2006. 09.018

Slomianka, L., Amrein, I., Knuesel, I., Sørensen, J. C., and Wolfer, D. P. (2011). Hippocampal pyramidal cells: the reemergence of cortical lamination. Brain Struct. Funct. 216, 301-317. doi: 10.1007/s00429-0110322-0

Slomianka, L., and West, M. J. (2005). Estimators of the precision of stereological estimates: an example based on the CAl pyramidal cell layer of rats. Neuroscience 136, $757-$ 767. doi: 10.1016/j.neuroscience. 2005.06.086

Sloviter, R. S. (1989). Calcium-binding protein (calbindin-D28k) immunocytochemistry: localization in the rat hippocampus with specific reference to the selective vulnerability of hippocampal neurons to seizure activity. J. Comp. Neurol. 280, 183-196. doi: $10.1002 /$ cne. 902800203

Sloviter, R. S., Sollas, A. L., Barbaro, N. M., and Laxer, K. D. (1991). Calcium-binding protein (calbindinD28K) and parvalbumin immunocytochemistry in the normal and epileptic human hippocampus. J. Comp. Neurol. 308, 381-396. doi: 10.1002/cne.903080306

Smit, H. A., Jansen Van Vuuren, B., O'brien, P. C. M., FergusonSmith, M., Yang, F., and Robinson, T. J. (2011). Phylogenetic relationships of elephant-shrews (Afrotheria, Macroscelididae). J. Zool. Lond. 284, 133-143. doi: 10. 1111/j.1469-7998.2011.00790.x

Soriano, E., Del Río, J. A., Martínez, A., and Supèr, H. (1994). Organization of the embryonic and early postnatal murine hippocampus. I. Immunocytochemical characterization of neuronal populations in the subplate and marginal zone. J. Comp. Neurol. 342, 571-595. doi: 10.1002/cne.903420406

Stephan, H. (1961). Vergleichendanatomische Untersuchungen an Insektivorengehirnen. V. Die quantitative Zusammensetzung der Oberflächen des Allocortex. Acta Anat. 44, 12-59.

Stephan, H. (1975). Allocortex. Berlin: Springer Verlag.

Stephan, H. (1983). Evolutionary trends in limbic structures. $\mathrm{Neu}$ rosci. Biobehav. Rev. 7, 367-374. doi: 10.1016/0149-7634(83)90041-6

Stephan, H., and Andy, O. J. (1964). Quantitative comparisons of brain structures from insectivores to primates. Amer. Zool. 4, 59-74. doi: 10.1093/icb/4.1.59

Stephan, H., and Spatz, H. (1962). Vergleichend-anatomische Untersuchungen an Insektivorengehirnen IV. Gehirne afrikanischer Insektivoren. Versuch einer Zuordnung von Hirnbau und Lebensweise. Gegenbaurs Morphol. Jahrb. 103, 108-174.

Tóth, K., and Freund, T. F. (1992). Calbindin D28k-containing nonpyramidal cells in the rat hippocampus: their immunoreactivity for GABA and projection to the medial septum. Neuroscience 49, 793-805. doi: 10.1016/0306-4522(92)90357-8

Trejo, J. L., Cuchillo, I., Machin, C., and Rua, C. (2000). Maternal adrenalectomy at the early onset of gestation impairs the postnatal development of the rat hippocampal formation: effects on cell number and differentiation, connectivity and calbindin 
D28k immunoractivity. J. Neurosci. Res. 62, 644-667. doi: 10.1002/10974547(20001201)62:5<644::AID-

JNR4 $>3.0 . \mathrm{CO} ; 2-3$

Villa, A., Podini, P., Panzeri, M. C., Racchetti, G., and Meldolesi, J. (1994). Cytosolic $\mathrm{Ca}^{2+}$ binding proteins during rat brain aging: loss of calbindin and calretinin in the hippocampus, with no change in the cerebellum. Eur. J. Neurosci. 6, 14911499. doi: 10.1111/j.1460-9568.1994. tb01010.x

West, M. J. (1993). Regionally specific loss of neurons in the aging human hippocampus. Neurobiol. Aging 14, 287-293. doi: 10.1016/0197-4580 (93)90113-P

West, M. J., and Gundersen, H. J. G. (1990). Unbiased stereological estimation of the number of neurons in the human hippocampus. J. Comp. Neurol. 296, 1-22. doi: $10.1002 /$ cne. 902960102
West, M. J., Slomianka, L., and Gundersen, H. J. G. (1991). Unbiased stereological estimation of the total number of neurons in the subdivisions of rat hippocampus using the optical fractionator. Anat. Rec. 231, 482-497. doi: 10.1002/ar.1092310411

Williams, P. A., Larimer, P., Gao, Y., and Strowbridge, B. W. (2007). Semilunar granule cells: glutamatergic neurons in the rat dentate gyrus with axon collaterals in the inner molecular layer. J. Neurosci. 27, 13756-13761. doi: 10.1523/JNEUROSCI.4053-07. 2007

Witter, M. P. (2006). Connections of the subiculum of the rat: topography in relation to columnar and laminar organization. Behav. Brain Res. 174, 251-264. doi: 10.1016/j.bbr. 2006.06.022

Wouterlood, F. G., Grosche, J., and Härtig, W. (2001). Co-localization of calretinin and calbindin in distinct cells in the hippocampal formation of the rat. Brain Res. 922, 310-314. doi: 10.1016/S0006-8993(01)03220-6

Xie, Z., Ma, X.-H., Ji, W., Zhou, G., Lu, Y., Xiang, Z., et al. (2010). Zbtb20 is essential for the specification of CAl field identity in the developing hippocampus. Proc. Natl. Acad. Sci. U.S.A. 107, 6510-6515. doi: 10.1073/pnas.0912315107

Conflict of Interest Statement: The authors declare that the research was conducted in the absence of any commercial or financial relationships that could be construed as a potential conflict of interest.

Received: 28 May 2013; paper pending published: 15 June 2013; accepted: 26 September 2013; published online: 29 October 2013.

Citation: Slomianka L, Drenth T, Cavegn $N$, Menges D, Lazic SE, Phalanndwa
M, Chimimba CT and Amrein I (2013) The hippocampus of the eastern rock sengi: cytoarchitecture, markers of neuronal function, principal cell numbers, and adult neurogenesis. Front. Neuroanat. 7:34. doi: 10.3389/fnana.2013. 00034

This article was submitted to the journal Frontiers in Neuroanatomy.

Copyright (c) 2013 Slomianka, Drenth, Cavegn, Menges, Lazic, Phalanndwa, Chimimba and Amrein. This is an openaccess article distributed under the terms of the Creative Commons Attribution License (CC BY). The use, distribution or reproduction in other forums is permitted, provided the original author(s) or licensor are credited and that the original publication in this journal is cited, in accordance with accepted academic practice. No use, distribution or reproduction is permitted which does not comply with these terms. 